\title{
A DIFFERENCIÁLT OKTATÁS HATÁSÁRA VÁLTOZÓ SZEMÉLYISÉGJELLEMZŐK: AZ ÖNÉRTÉKELÉS TERÜLETEINEK FEJLŐDÉSE FELSŐ TAGOZATOS TANULÓKNÁL
}

\author{
Szerző: \\ Kós Nóra \\ Gál Ferenc Főiskola
}

Szerző e-mail címe:

kosnora@gmail.com

\section{Lektorok:}

Tóth László

Debreceni Egyetem

Szilágyi Barnabás

Debreceni Egyetem

Mező Katalin

Debreceni Egyetem

Mező Ferenc

Debreceni Egyetem

Kós Nóra (2015): A differenciált oktatás hatására változó személyiségjellemzők: az önértékelés területeinek fejlődése felső tagozatos tanulóknál. Különleges Bánásmód, I. évf.

2015/3. szám, 21-42. DOI 10.18458/KB.2015.3.21

\begin{abstract}
Absztrakt
E longitudinális kutatás (2006-2010) központi kérdése, hogy a differenciált oktatásnak pozitív hatása van-e a felsö tagozatos tanulók önértékelésére. Minta: $n=354$ személy (177 tanuló a vizsgálati csoportban, 177 tanuló a kontrollcsoportban), életkor: 10-14 év. Módszer: Coopersmith-féle önértékelési kérdöivvel történt a fejlesztés elött, után és három alkalommal közben (ez összesen tehát 5 mérési alkalmat jelent). Eredmény: az ellenörzött és tervezett differenciált fejlesztésnek szignfikáns hatása van a pozitív önértékelésre és az iskolai teljesítményre is.
\end{abstract}

Kulcsszavak: önértékelés/önbecsülés, differenciált oktatás, iskolai önértékelés, családi önértékelés, társakhoz füződő viszony.

Diszciplína: pszichológia, pedagógia

\begin{abstract}
CHANGING PERSONAL CHARACTERISTICS THROUGH DIFFERENTIATED EDUCATION: DEVELOPMENT OF AREAS OF SELF-ESTEEM IN UPPER GRADE ELEMENTARY SCHOOL STUDENTS

The central question of this longitudinal research (2006-2010) is whether the differentiated education has positive effects on the self-esteem of upper grade elementary school students. Sample: $n=354$ persons (177 students in the examination group, 177 students in the contro lgroup), age: 10-14 years. Method: Coopersmith's Self-esteem inventory was applied before, after and three times during the development (a total of 5 occasions of measurment). Result:
\end{abstract}


the controlled and planed differentiated development has significant impact on positive selfesteem and school achievement.

Keywords: self-esteem, differentiated education, school self-esteem, family self-esteem, relation to contemporary groups

Disciplines: psychology, pedagogy

A tanulók közötti különbségek felismerése erősen hangsúlyos terület a pszichológiában és a pedagógiában. A tanítás folyamata során figyelembe kell venni a tanuló személyiségét, értelmi és más kognitív képességeit, kitartását, szorongási szintjét és még számos területet, amelyek meghatározzák a teljesítményt. Kutatások sora bizonyítja, hogy a pedagógus által ezek alapján megválasztott tanítási módszer segítheti a diákot abban, hogy a lehető legjobb eredményt hozza ki magából. Akár a nemzetközi (Marshall, 1997), akár a hazai kutatások (Réthyné, 2003) azt mutatják, hogy az általános iskolát tekintve a motiváció az, amely meghatározza a tanulók teljesítményét. Ennek egyik eszköze a differenciálás lehet. A differenciálásról alkotott képe a pedagógusoknak egyre inkább formálódik az ismeretek és a gyakorlati tapasztalatok hatására. Ezt mutatja Petriné és munkatársai újabb kutatása (Petriné, 2001). Ez természetesen nem azt jelenti, hogy a megfelelő módszer kiválasztása esetében mindenki kitünő tanulóvá válik, de ha pozitív hozzáállást alakítunk ki a tanulóban, akkor eredményesebb lesz a munkája, megkedveltethetjük vele az adott tárgyat. A differenciált oktatás erre irányul.

E tanulmányban azt mutatjuk be, hogy az általunk választott korcsoportban mennyire meghatározó a differenciált oktatás a személyiség fejlődésére, közelebbről az önértékelésre nézve. Ennek meghatározásához a 10-14 éves tanulók önértékelését tettük vizsgálat tárgyává.

Akár a hazai, akár a nemzetközi kutatások eredményeit vizsgáljuk, megerősítést kapunk abban, hogy az énkép befolyásolja a teljesítményt. Ha figyelembe vesszük a pozitív és negatív énkép következményét, akkor megállapítható: a negatív énkép és az alacsony teljesítményszint között statisztikailag is szoros összefüggés igazolható (Brookover, 1959). A negatív énkép a teljesítményen kívül hatással van a magatartásra és a pszichés fejlődésre, gyakran eredményez agresszív megnyilvánulásokat (Kőrössy, 1997).

Másfelől vannak elméletek, melyek azt feltételezik, hogy a teljesítmény van hatással az énkép fejlődésére, nem pedig fordítva. Helmke és Van Aken (1995) longitudinális kutatása ebbe a csoportba tartozik.

\section{Önértékelés vagy önbecsülés - elméleti háttér}

Bár az önértékelésnek több meghatározása is van, ezek nagyjából egyeznek abban, hogy az önértékelés az a mód, ahogyan az ember értékeli saját testi jellemzőit, képességeit és személyiségvonásait. Tudományos tény, hogy az önértékelés motivált. A motívumok azok, amelyek befolyásolják, miként választja ki az ember az én-releváns információt, miként méri fel a valóságot, miként von le következtetéseket magáról, és miként sző terveket a jövőre nézve (Dauenbeimer és mtsai, 2002).

Az önértékelésnek szoros kapcsolata van az önbecsüléssel és az önérték-érzettel. Itt két modellről tehetünk említést. Az önbecsülés kognitív (bottom-up) modellje az értékelö feedback-ből indul ki, ez befolyásolja az önértékelést, ami aztán az önérték-érzetre és a globális önbecsülésre van hatással. Az önbecsülés affektív (top-down) modellje viszont a 
globális önbecsülésböl és az értékelö feedback-böl indul ki, melyek az önértékelésre vannak hatással, az önértékelés pedig az önérték-érzetet befolyásolja (Brown és Marshall, 2006 - 1. és 2. ábra). E szerzők az utóbbi álláspont hívei, míg például Coopersmith (1967, 1982) a kognitív nézőpont képviselője.

1. ábra: az önbecsülés kialakulásának és müködésének kognitív (bottom-up) modellje

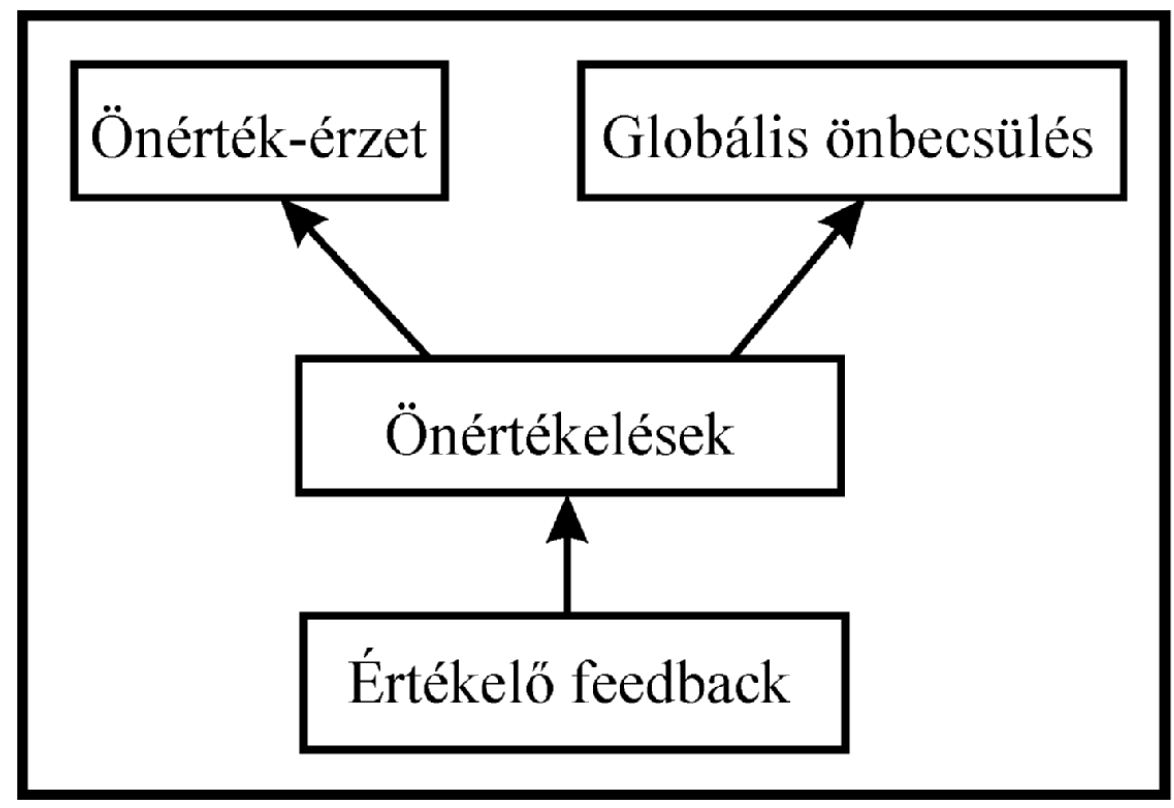

2. ábra: az önbecsülés kialakulásának és müködésének affektív (top-down) modellje

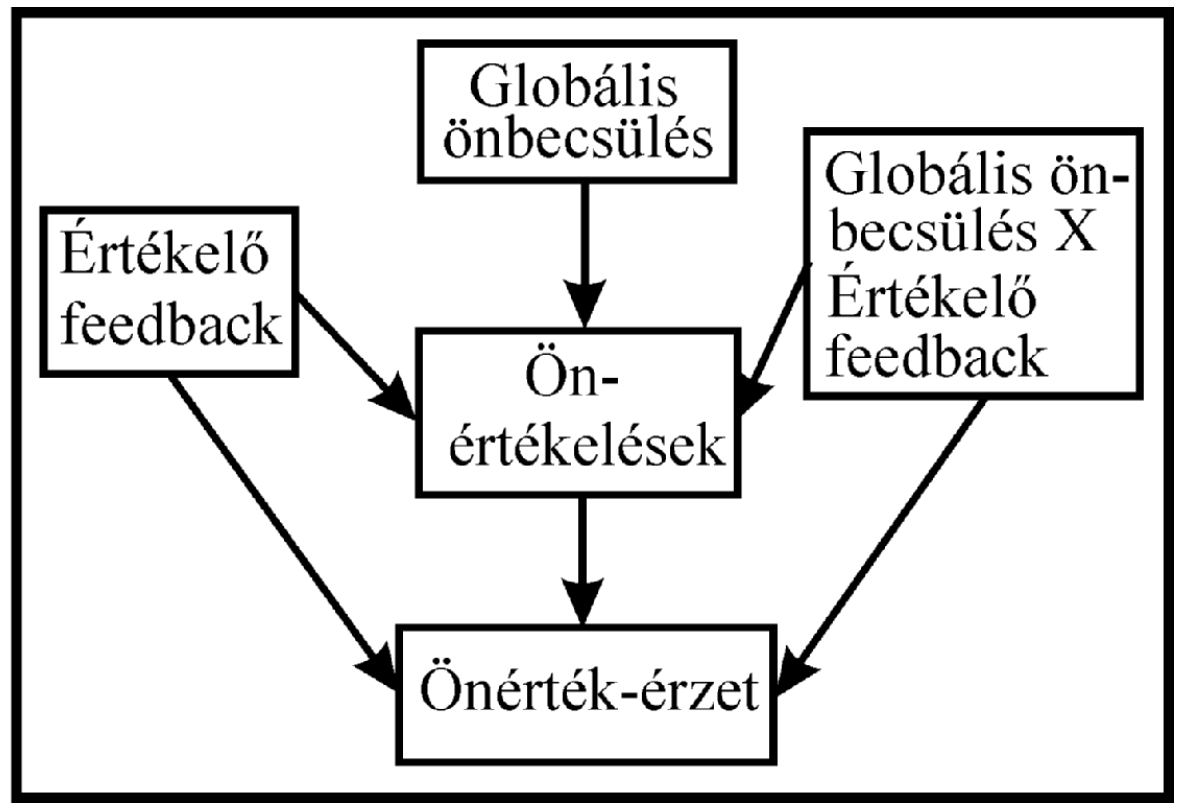


Nem tisztünk most valamelyik modell mellett érvelni, illetve állást foglalni, azonban meg kell jegyeznünk, hogy bár a fentebb említett három fogalom elkülönítése elméleti szempontból mindenképpen indokolt, a gyakorlatban az önértékelés és az önbecsülés fogalma gyakran összemosódik, sokan a kettőt felváltva használják (mint ahogy az „önérték”, „öntisztelet” vagy „énintegritás” és más variációkat is). Bizonyítékként elég az internet tengernyi szakoldalára hivatkozni. Magunk azon a véleményen vagyunk, hogy az önbecsülés az önértékelésből következik, és nem fordítva. Vagyis: az egyén az önértékelés folyamata révén információt gyüjt magáról (ahogy ő magát látja és ahogyan őt mások látják), és a begyüjtöttek fényében dönt arról, hogy mire tartja magát. Az önbecsülést (self-esteem) nem szabad összetéveszteni az önbecsléssel (self-assessment), mivel az utóbbi egy eszköz gondoljunk csak az önbecslő skálákra.

Az önbecsülést meg kell különböztetni az énkép sokkal általánosabb fogalmától, mivel sokan ugyanazt értik a két fogalmon. Az énkép azon kognitív vélekedések összességére utal, amelyekkel az egyén magáról rendelkezik, minden, amit tud magáról, magában foglal olyan dolgokat, mint a név, faji hovatartozás, mit szeret - mit nem szeret, miben hisz, mit tart értékesnek, de idetartoznak a külső megjelenést leíró dolgok is, mint a magasság és a súly. Ezzel szemben az önbecsülés egyfajta érzelmi válasz arra, amit az emberek tapasztalnak, amikor az önmagukkal kapcsolatos különböző dolgokkal foglalkoznak, és azokat értékelik.

Az önbecsülésre vonatkozó elméletek általában azt hangsúlyozzák, hogy az embernek egy egészséges, pozitív kép kialakítása magáról és másokról öröklötten emberi jellemző. Vagyis minden ember egyfajta önbecsülési képességgel születik, amely természetét tekintve magas szintü. Nyilvánvalóan valaminek történnie kell vele az élete során, ami ezt a magas szintü önbecsülést fenntartja, illetve lerombolja. Utóbbinál (self-degradálás) legtöbbször a beépített értékek megszegéséért való önbüntetést, külső negatív hatásokat vagy a szánalom hiányát szokás emlegetni (Goserud, 2015).

Az önbecsülés elméletei sokfélék. Két irányvonal látszik azonban kibontakozni. Az egyik az önbecsülést a személyes értékesség vagy értéktelenség stabil jellemzőnek tartja. A másik irányvonal szerint az önbecsülés inkább kompetencia-alapú, és az egyén azon képességéből származik, aminek birtokában eredményesen tud megküzdeni az élet kihívásaival, és értékesnek, illetve boldognak tekinti magát.

Arra, hogy melyik irányvonalnak van igaza, nem kell válaszolnunk. Mint ahogy minden terület, az önbecsülés területe is folyamatosan gazdagodik, változik a kutatások során, így a belölük levont következtetések az elméleteket is módosítják. Jelenleg az látszik igaznak, hogy az önbecsülés az egyén azon mentális és emocionális képességéből származik, amelyekkel kezelni tudja az új szituációkat még akkor is, ha azok kimenetele ismeretlen (Goserud, 2015)).

Ami az önbecsülés szintjeit illeti, alacsony, átlagos és magas önbecsülésröl beszélhetünk. Ez a mérési módszer az önbecsülési skála minden szintjéhez specifikus jellemzőket ad meg. Ezeket a személyiségvonásokat általában mint határvonalakat használják annak meghatározására, hogy a vizsgált személynek előnye származhat-e egy olyan terápiából, amely az alacsony önbecsülés emelését célozná. Az önbecsülés mérése ugyanis - legalábbis klinikai szempontból - elsősorban, de nem kizárólagosan az alacsony önbecsülés azonosítását célozza.

$\mathrm{Az}$ alacsony szintü önbecsülés az átlagtól eltérő viselkedéseket hordoz, áthatja az egyén életét, a megélt élet minőségét negatív irányba befolyásolja. Az alacsony önbecsülésben szenvedő egyén értéktelen embernek érzi magát, $\mathrm{s}$ emiatt nehezen ért szót másokkal. Szégyelli magát még akkor is, ha adott helyzetben vétlen volt. Nehezen tudja konstruktív módon kifejezni az érzelmeit. Adott szituációban mindig a legrosszabbra számít. A krónikusan alacsony önbecsülésủ ember mindemellett egészségi problémákkal is küzd, mint például evészavar, depresszió és generalizált szorongás.

Az átlagos szintü önbecsülés nem azt jelenti, hogy adott személy az önbecsülés minden területén átlagos, hanem azt, hogy egyik területen nagyra tartja magát, a másik területen 
viszont kevésre. Így jön ki az átlag. De éppen ezért a viselkedése nem megjósolható. Könnyen előfordulhat, hogy olykor meggondoltan, kiszámíthatóan viselkedik, máskor pedig meggondolatlanul, impulzív módon cselekszik.

A magas önbecsülést gyakran ideális célnak tekintik, amelyet bárki elérhet, ha fejleszti az énképét. A magas önbecsülésü egyén tanul a múltbeli hibáiból anélkül, hogy szégyellené azokat, jó kapcsolata van mindenkivel, és őszintén hiszi, amit gondol. Ugyanakkor az önbecsülés magas szintje nem feltétlenül előnyös, ugyanis bizonyos negatív vonások megjelenésének kedvez. Ilyen például az, amikor valaki feljogosítva érzi magát mindenre (Goserud, 2015).

$\mathrm{Az}$ iskolai oktatás természetesen nem a klinikum, mindazonáltal a pedagógust (akinek kötelessége a személyiség fejlesztése) érdekelheti a tanulók önbecsülése bizonyos területeken elsősorban azért, hogy kihez-kihez hogyan viszonyuljon, adott tanuló esetében mit tegyen vagy ne tegyen, milyen oktatásszervezési módot válasszon vagy ne válasszon az oktatási célok mellett a személyiségfejlesztési célok megvalósítása érdekében.

Ami az önbecsülés fejlődését illeti, az eddigi kutatások nem teszik lehetővé valamilyen általános tendencia felvázolását. Robins és mtsai (2002) 80 vonatkozó kutatás anyagát elemezték, Pullmann és mtsai (2009) viszont óriási mintán végeztek kutatást, és mindannyian arra a következtetésre jutottak, hogy a kutatási eredmények ellentmondóak. Vannak kutatók, akik gyermekkorban magas, mások alacsony, megint mások átlagos önbecsülést találtak; aztán vannak kutatók, akik szerint serdülőkorban emelkedik, mások szerint csökken, megint mások szerint nem változik az önbecsülés, és a sort lehetne folytatni.

Annyit azért elmondhatunk, hogy az önbecsülés fejlődését elsősorban a szülői-nevelöi attitüd határozza meg, másodsorban pedig fontos szerepet játszanak az iskola és a kortársak is. A pedagógusok számára eligazító lehet Tókos (2005) tanulmánya, amely az énkép, önértékelés, önismeret pedagógiai jelentőségére mutat rá.

A fentiek részletezését azért tartottuk fontosnak, mert longitudinális kutatásunk az önértékelés/önbecsülés feltárását célozta meg annak kiderítésére, hogy a differenciált oktatás hogyan befolyásolja ennek alakulását, személyiségfejlesztési szempontból előnyös-e a differenciált oktatás. Mivel a Coopersmith-féle önbecsülési kérdöív alkalmasnak tủnt az önbecsülés különböző területeinek megragadására, ezért esett választásunk erre a módszerre.

Elméleti fejtegetésünk befejezéseként (stílszerüen) ideírjuk Coopersmith-nek az önbecsülésre vonatkozó meghatározását. „Az önbecsülés az értékesség személyes megítélése, amely az egyénnek az önmagára irányuló attitüdjeiben fejeződik ki." (Coopersmith, 1967, 45.).

\section{A kutatás bemutatása}

Jelen kutatási beszámoló részét képezi egy nagyobb ívü vizsgálatsorozatnak, melynek célja annak kiderítése, hogy a differenciált oktatás mennyiben előnyös különböző személyiségjellemzőkre nézve. Ebben a beszámolóban csak az önértékelés/önbecsülés vizsgálatát mutatjuk be. Végeredményben egyetlen hipotézisünk van, az, hogy előnyös. Pedagógiai oldalról - legalábbis a megfigyelések szintjén - ez eldőlni látszik, de pszichológiai oldalról erre vonatkozóan mindeddig nem végeztek tudományos igényü vizsgálatokat.

\section{Minta}

A két vizsgálati csoport (kísérleti és kontrollcsoport) kiválasztása teljesen véletlenszerü volt. Arra törekedtünk, hogy az ország különböző kis és nagyobb városaiban legyenek kísérleti és kontrollosztályok egyaránt. A fejlesztő csoport Dombrád, Mátészalka, Nagyszénás, Szolnok, Hajdúböszörmény, Szarvas, Szeghalom iskoláiból, a kontrollcsoport Szentes, Békéscsaba, 
Komádi, Paks, Mezőkovácsháza, Nyírbátor iskoláiból szerveződött. A pszichológiai tesztek felvétele az adott általános iskolában osztálytermi keretek között történt, a pedagógusok és általunk lettek felvéve. A tesztek kitöltése minden évben két-két alkalommal történt, hiszen figyelembe kellett venni a tanulók figyelmét és terhelhetőségét (első alkalom: énkép és közösség iránti beállítódás teszt, második alkalom: szorongás és önértékelés kérdöív). A vizsgálatok megkezdése előtt a szülők egy tájékoztatón vettek részt, majd ezt követően írásban hozzájárultak a tesztek felvételhez (lásd a 2. mellékletet).

A vizsgált életkor: 10-14 éves tanulók (5-6-7-8. évfolyam folyamatos vizsgálata)

Résztvevők, létszám: csak azoknak a tanulóknak az adatait dolgoztuk fel, akik az összes mérésben részt vettek. Az 1. táblázat ezt tükrözi.

1. táblázat: résztvevők, létszám (forrás: a Szerzö)

\begin{tabular}{|l|c|c|c|}
\hline \multicolumn{1}{|c|}{ Csoport } & Fiú & Lány & Összesen \\
\hline Fejlesztő csoport & 86 & 91 & 177 \\
\hline Kontrollcsoport & 83 & 94 & 177 \\
\hline
\end{tabular}

A kutatás a 2006/2007-es tanévben kezdődött és a 2009/2010-es tanévben fejeződött be. A négy évig tartó, a felső tagozat teljes időtartamára kiterjedő kutatás keretében kísérleti és kontrollcsoportok alkalmazásával kívántuk igazolni azt a feltételezést, hogy a differenciált fejlesztésben részesülő tanulók (kísérleti csoport) bizonyos személyiségjellemzőinek változása nagyobb mértékü, mint a differenciált fejlesztésben nem részesülö tanulók (kontrollcsoport) ugyanezen jellemzőinek változása. A következökben a fejlesztő csoport négy éves kutatásának eredményeit mutatjuk be az önértékelés/önbecsülés vonatkozásában. A bemeneti mérés 5. osztály szeptemberében, a további mérések 5., 6., 7., 8., osztály májusában történtek.

A differenciált fejlesztéshez az oktatócsomagokat a Szent István Egyetem Pedagógiai Kara, Szarvas tantárgypedagógiai csoportjai készítették havi bontásban, melyért ezúton is köszönetet mondunk.

\section{Vizsgálati módszer}

Mérések száma: 5. évfolyam év elején és végén, 6., 7. és 8. évfolyamon egy mérés történt a kontroll és a fejlesztő csoportokban is. A fejlesztő (kísérleti) csoportokban folyamatos differenciált oktatás történt, míg a kontrollcsoportokban nem.

Az önértékelés mérésére a Coopersmith által 1967-ben kidolgozott kérdöívet alkalmaztuk. A teszt alkalmas általános iskolás és középiskolás tanulók önértékelésének vizsgálatára. A teszt reliabilitására és validitására irányuló vizsgálatok mindegyike azzal zárult, hogy a teszt megbízható és érvényes adatokat szolgáltat (Net1; Blascovich és Tomaka, 1990)

A kérdőív öt alskálát tartalmaz. Ebből négy az önértékelés egyes összetevőit tartalmazza, az ötödik pedig ellenőrző jellegü (,hazugság skála”), a társadalmi elvárásokhoz való igazodást méri. Ez utóbbit nem számítjuk bele az általános önérték-indexbe. Az egyes skálák a következők:

1. S skála. Ebbe a skálába a közvetlenül a „self”-re vonatkozó tételek tartoznak. Ezek magára a gyermek önértékelésére vonatkoznak: mennyire magabiztos, mennyire elégedett magával (26 tétel). 
2. I skála. Ez az iskolára vonatkozó alskála. Itt elsősorban arról van szó, hogy a gyermek mennyire elégedett saját iskolai eredményességével, mennyire bízik értelmi téren saját sikerességében (8 tétel).

3. O skála. Az otthoni hatások önértékeléssel kapcsolatos részét méri: mennyi bizalommal és megértéssel követelnek a gyermektől a szülei (8 tétel).

4. T skála. Az egykorú társakkal való viszonyban kifejeződő önértékelés mutatója (8 tétel).

5. L skála. A szociális konformizmus skálája (8 tétel).

A pontozás úgy történik, hogy 2 pontot adunk minden egyes kódolási kulcsnak megfelelő tételre. Például, ha a gyermek az 1. tételnél $(-S)$ a Nem jellemző rám rovatba tette a jelet, 2 pontot kap, ha a Jellemző rám rovatba tette a jelet, nem kap pontot az $\mathrm{S}$ alskálában. Az első négy skála összege adja az általános önérték-indexet. (A kérdőívet és a kódolási kulcsot az 1. melléklet tartalmazza.)

Ügyelni kell arra, hogy mindenütt legyen jel, s egyértelmű helyen. Ha egy-két esetben nem világos a válasz, akkor az adott tételre 1 pontot adunk.

Az értékelésnél a kódtábla elemeit kell alapul venni, és ennek megfelelöen határozhatóak meg az egyes területen a pontszámok. Ezt követően a Coopersmith-féle kérdőívvel nyert (nem reprezentatív) magyar adatok átlagaival is összehasonlíthatjuk a felvett adatokat (Tóth, 2005).

Megjegyezzük, hogy a kérdőívnek felnőttek számára készített, és rövidített változata is létezik.

\section{Vizsgálati eredmények}

Az eredmények értékeléséhez a leíró statisztikai (átlag, szórás) számítások mellett kétmintás t-próbát, és varianciaanalízist is alkalmaztam. A varianciaanalízis a normál eloszlású csoportok átlagainak összevetésére alkalmas módszer, amely a jelen kutatásban az átlagok változását mutatja be az idő függvényében, a fejlesztő és kontrollcsoportra, illetve a nemekre nézve (a függő változó az önértékelés alskálái, a független változók pedig az idő, a csoportok és a nemek).

A kétmintás t-próba vizsgálja két külön mintában a változók szignifikáns eltéréseit, Fpróbával vizsgálom a szórás egyezőséget a mintákban (4-6. táblázat). Az 2. táblázatban a fejlesztő csoportok átlagának különbségét a bemeneti és a kimeneti időszakban. A következőkben ezzel a statisztikai módszerrel mutatom be a nemek eltérésében és a fejlesztési idő hatására elért eredményeket.

A 2. táblázatban. A 2. táblázat alapján (ami a 2006-2009 évi fejlesztő - kísérleti - csoport mérési eredményeit foglalja össze) a következő skála eredmények láthatóak: „S” alskála, az önértékelés a gyermek elégedettségére vonatkozó mérés átlagok különbsége bemenet és kimenet: 7,39 (bemenet: 24,64, kimenet. 32,03), ami pozitív fejlődést mutat a fejlesztő csoportban. A megfelelő önértékeléssel rendelkező gyermek elégedett önmagával, ,jól érzi magát a börében", eredményesen és könnyen alakít ki kapcsolatot környezetével, általában optimista, felelősségteljes. A differenciált fejlesztések hatására az önértékelés fokozottan fejlődik, ami a tanulási folyamatot is elősegíti.

Az „I” alskála, az iskolai sikerességet, az iskolához való viszony átlagok különbsége bemenet és kimenet: 2,07 (bemenet: 6,88, kimenet: 8,95), ami nagyon minimális fejlődést mutat a fejlesztő csoportban. A folyamatos kudarc élmény hatására a tanulók teljesítménye és magatartása negatív irányban változik ebben az életkorban. Azonban a gyermek pozitív megerősítése, az iskolához füződő pozitív viszonya segíti a tanulót a kudarcainak leküzdésében és a konfliktuskezelésben.

Az „O” alskála, az otthoni önértékelés, az elfogadás átlagok különbsége bemenet és kimenet: 1,66 (bemenet: 9,48, kimenet: 11,14), ami szintén minimális eltérést mutat. Az 
önértékelés fejlődésében az intézmények, a pedagógusok és a kortársak mellett kiemelkedő szerepe van a szülőknek. A differenciált fejlesztés mellett a szülők otthoni pozitív megerősítése gyengítheti vagy erösítheti az önértékelés változását. Ebben az esetben a folyamatos fejlesztő tevékenységek mellett az otthoni önértékelés nagyon minimális fejlődést mutat.

2. táblázat: Az önértékelés átlagai és szórásai a fejlesztö csoportokban (2006-2009 _ forrás: a Szerzö)

\begin{tabular}{|c|c|c|c|c|c|c|c|c|c|c|c|c|}
\hline \multirow[t]{2}{*}{ Skála } & \multirow[t]{2}{*}{ Nem } & \multicolumn{2}{|c|}{$\begin{array}{l}\text { 1. mérés } \\
\text { (bemenet) }\end{array}$} & \multicolumn{2}{|c|}{ 2. mérés } & \multicolumn{2}{|c|}{ 3. mérés } & \multicolumn{2}{|c|}{ 4. mérés } & \multicolumn{2}{|c|}{$\begin{array}{l}\text { 5. mérés } \\
\text { (kimenet) }\end{array}$} & \multirow{2}{*}{$\begin{array}{c}\text { Átlagok } \\
\text { különbsége } \\
\text { bemenet és kimenet } \\
\text { között }\end{array}$} \\
\hline & & átlag & szórás & átlag & szórás & átlag & szórás & átlag & szórás & átlag & szórás & \\
\hline \multirow{3}{*}{$\mathbf{S}$} & fiú & 24,82 & 7,975 & 24,59 & 8,66 & 24,84 & 8,65 & 31,43 & 8,89 & 31,98 & 7,64 & 7,16 \\
\hline & lány & 24,47 & 8,491 & 24,81 & 8,106 & 24,81 & 7,97 & 29,69 & 8,23 & 32,09 & 6,402 & 7,62 \\
\hline & összesen & 24,64 & 8,21 & 24.70 & 8,36 & 24.82 & 8,29 & 30,55 & 8,58 & 32,03 & 7,02 & 7,39 \\
\hline \multirow{3}{*}{ I } & fiú & 7,23 & 3,60 & 6,66 & 3,66 & 6,93 & 3,62 & 7,95 & 3,12 & 8,53 & 2,77 & 1,3 \\
\hline & lány & 6,54 & 3,52 & 6,94 & 3,45 & 6,88 & 3,47 & 7,62 & 2,81 & 9,36 & 2,51 & 2,82 \\
\hline & összesen & 6,88 & 3,57 & 6,80 & 3,55 & 6,90 & 3,54 & 7,79 & 2,96 & 8,95 & 2,67 & 2,07 \\
\hline \multirow{3}{*}{$\mathbf{O}$} & fiú & 9,41 & 4,08 & 9,39 & 4,45 & 9,34 & 4,31 & 10,36 & 3,69 & 10,98 & 3,61 & 1,57 \\
\hline & lány & 9,66 & 4,08 & 9,69 & 4,10 & 9,73 & 3,87 & 10,58 & 3,68 & 11,30 & 3,30 & 1,64 \\
\hline & összesen & 9,48 & 4,15 & 9,62 & 4,18 & 9,54 & 4,09 & 10,47 & 3,68 & 11,14 & 3,485 & 1,66 \\
\hline \multirow{3}{*}{$\mathbf{T}$} & fiú & 9,45 & 3,49 & 9,48 & 3,31 & 10,14 & 3,14 & 12,16 & 3,31 & 12,20 & 3,67 & 2,75 \\
\hline & lány & 9,39 & 3,15 & 9,55 & 3,23 & 10,36 & 3,00 & 11,82 & 3,22 & 12,56 & 3,77 & 3,17 \\
\hline & összesen & 9,42 & 3,31 & 9,51 & 3,26 & 10.25 & 3,07 & 11,99 & 3,26 & 12,38 & 3,72 & 2,96 \\
\hline \multirow{3}{*}{ Önérték index } & fiú & 50,91 & 15,93 & 50,11 & 17,25 & 50,57 & 16,87 & 61,05 & 15,15 & 62,32 & 13,36 & 11,41 \\
\hline & lány & 49,96 & 16,41 & 51,10 & 15,22 & 50,88 & 15,14 & 59,15 & 14,07 & 63,01 & 12,47 & 13,04 \\
\hline & összesen & 50,43 & 16,13 & 50,61 & 16,22 & 50,72 & 15,98 & 60,09 & 14,61 & 62,67 & 12,89 & 12,24 \\
\hline
\end{tabular}

A „T” alskála, a társakkal való viszony átlagok különbsége bemenet és kimenet: 2,96 (bemenet: 9,42, kimenet: 12,38), ami egy kicsivel nagyobb eltérést mutat a fejlesztések hatására. A kortársak iránti érdeklődés az általunk vizsgált életkorú tanulóknál kiemelkedő fontosságú, hiszen egyrészt meghatározó a tanulás iránti érdeklődésben, másrészt az önértékelés fejlődését is befolyásolja. Ebben az esetben a differenciált fejlesztés hatására pozitívan fejlődött a társakhoz való viszony, ami pozitív hatással volt a csoport fejlődésére és a csoporton belüli személyek fejlődésére.

És végül az önérték index átlagok különbsége bemenet és kimenet: 12,24 (bemenet: 50,43, kimenet: 62,67), ami azt mutatja, hogy az önérték indexben változás tapasztalható mindkét nem esetében. Összességében elmondható, hogy a fejlesztő csoport önértékelése a differenciált oktatás következtében mindegyik alskálában fejlődést mutatott, de leginkább az önértékelés és a társakkal való viszony alskálában történt nagyobb fejlődés.

A 3. táblázatban a 2006-2009 évi kontrollcsoport mérési eredményei láthatók: „S” alskála, az önértékelés átlagok különbsége bemenet és kimenet: 5,44 (bemenet: 24,13, kimenet: 29,58) az életkori fejlődés jellemzői miatt pozitív eltérést mutat. A kontroll csoport önértékelés pozitív/negatív irányba való eltérésben pozitív fejlődést láthatunk. Az egészséges személyiség kialakulásához nélkülözhetetlen a pozitív önértékelés kialakulása. Ebben esetben látható a bemeneti mérésekhez képest a tanulók önértékelése pozitívan fejlődött az irányított fejlesztések nélkül.

„I” alskála, az iskolai önértékelés átlagok különbsége bemenet és kimenet: 1,33 (bemenet: 6,75, kimenet: 8,09), ami minimális eltérést mutat. A tanulás iránti motiváció alapfeltétele, hogy a tanuló iskolához való viszonya pozitív legyen. Ebben az esetben a tanulók iskolai önértékelése minimális változást mutat, ami a motiváltságot csökkenti a tanulókban, és nehezíti az új tananyag megtanulását és megértését. 
3. táblázat: Az önértékelés átlagai és szórásai a kontrollcsoportokban (2006-2009-forrás: a Szerzö)

\begin{tabular}{|c|c|c|c|c|c|c|c|c|c|c|c|c|}
\hline \multirow{2}{*}{ Skála } & \multirow{2}{*}{ Nem } & \multicolumn{2}{|c|}{$\begin{array}{l}\text { 1. mérés } \\
\text { (bemenet) }\end{array}$} & \multicolumn{2}{|c|}{ 2. mérés } & \multicolumn{2}{|c|}{ 3. mérés } & \multicolumn{2}{|c|}{ 4. mérés } & \multicolumn{2}{|c|}{$\begin{array}{l}\text { 5. mérés } \\
\text { (kimenet) }\end{array}$} & \multirow{2}{*}{$\begin{array}{c}\text { Átlagok } \\
\text { különb- } \\
\text { sége } \\
\text { bemenet } \\
\text { és kimenet } \\
\text { között }\end{array}$} \\
\hline & & átlag & szórás & átlag & szórás & átlag & szórás & átlag & szórás & átlag & szórás & \\
\hline \multirow{3}{*}{$\mathbf{S}$} & fiú & 24,11 & 8,68 & 24,14 & 8,66 & 25,34 & 8,05 & 27,52 & 9,89 & 29,14 & 9,70 & 5,03 \\
\hline & lány & 24,16 & 8,31 & 24,16 & 8,31 & 24,74 & 8,05 & 28,07 & 8,90 & 30,02 & 7,79 & 5,86 \\
\hline & összesen & 24,14 & 8,47 & 24,15 & 8,46 & 25,04 & 8,03 & 27,80 & 9,38 & 29,58 & 8,78 & 5,446 \\
\hline \multirow{3}{*}{ I } & fiú & 6,61 & 3,60 & 6,59 & 3,64 & 7,02 & 3,40 & 6,84 & 3,41 & 7,75 & 3,07 & 1,14 \\
\hline & lány & 6,90 & 3,58 & 6,88 & 3,58 & 6,81 & 3,44 & 7,35 & 2,98 & 8,43 & 3,26 & 1,53 \\
\hline & összesen & 6,76 & 3,58 & 6,73 & 3,60 & 6,92 & 3,41 & 7,10 & 3,20 & 8,09 & 3,18 & 1,333 \\
\hline \multirow{3}{*}{$\mathbf{O}$} & fiú & 9,25 & 4,40 & 9,25 & 4,40 & 9,50 & 4,08 & 9,59 & 4,33 & 10,16 & 4,07 & 0,91 \\
\hline & lány & 9,66 & 4,08 & 9,69 & 4,10 & 9,71 & 3,90 & 10,56 & 3,70 & 10,61 & 3,30 & 0,95 \\
\hline & összesen & 9,46 & 4,24 & 9,47 & 4,24 & 9,60 & 3,98 & 10,08 & 4,04 & 10,38 & 3,70 & 0,926 \\
\hline \multirow{3}{*}{$\mathbf{T}$} & fiú & 9,45 & 3,31 & 9,45 & 3,33 & 9,50 & 3,18 & 10,52 & 3,58 & 11,02 & 3,95 & 1,57 \\
\hline & lány & 9,26 & 3,26 & 9,26 & 3,26 & 9,55 & 3,25 & 10,97 & 3,54 & 10,65 & 3,81 & 1,39 \\
\hline & összesen & 9,36 & 3,28 & 9,36 & 3,29 & 9,53 & 3,21 & 10,75 & 3,55 & 10,84 & 3,87 & 1,48 \\
\hline \multirow{3}{*}{$\begin{array}{c}\text { Önér- } \\
\text { ték } \\
\text { index }\end{array}$} & fiú & 49,43 & 17,21 & 49,43 & 17,24 & 51,36 & 15,50 & 54,48 & 17.58 & 58,07 & 17,45 & 8,64 \\
\hline & lány & 49,98 & 15,68 & 49,98 & 15,74 & 50,81 & 15,28 & 56,94 & 14,79 & 59,71 & 13,86 & 9,73 \\
\hline & összesen & 49,71 & 16,41 & 49,71 & 16,46 & 51,08 & 15,35 & 55,72 & 16,23 & 58,89 & 15,72 & 9,187 \\
\hline
\end{tabular}

„O” alskála, a családi önértékelés átlagok különbsége bemenet és kimenet: 0,92 (bemenet: 9,45, kimenet: 10,38), ami szintén minimális eltérést mutat. Ebben az esetben is meghatározó a szülők és a tanuló kapcsolatának minősége. A minimális eltérés a bement és a kimenet eredménye között érezhető a tanulók fejlődéspszichológiai változásai, a serdülőkor pszichés változásainak hatására az otthoni önértékelés lassú fejlődést mutat. Az identitás fejlődésében meghatározó terület a serdülő önmaga keresése, a szülő-gyermek kapcsolat megváltozása.

„T” alskála, a társakkal való viszony átlagok különbsége bemenet és kimenet: 1,48 (bemenet: 3,28, kimenet: 10,83), ami viszonylag alacsony eltérést mutat. A kortársak hatása meghatározó ebben az életkorban. Ebben az esetben minimális fejlődés látható a négy év alatt, ami arra utal, hogy az osztályon belüli konfliktusok, klikkesedések nehezítik az osztály kohézióját, s ez kihat a tanulásra.

Az önérték index átlagok különbsége bemenet és kimenet: 9,18 (bemenet: 49,70, kimenet: 58,89), ami mutatja a tanulók válaszai közötti eltéréseket.

A 4. táblázatban látható, hogy a Levene féle F próba szignifikancia szintje $(p>0,05)$ alapján megegyezik a szórás. Látható, hogy a két csoport között minden skála esetében az első (bemeneti) mérésnél és a második mérésnél nincsen szignifikáns különbség ( $p>0,05)$. A társakkal való viszony ( $\mathrm{T}$ skála) esetében már a harmadik mérés, azaz 6. osztályban szignifikáns különbség $(\mathrm{p}<0,05)$ van a fejlesztő és a kontrollcsoport között. Az $\mathrm{S}$ (önértékelés), I (iskolai), T (társakkal való kapcsolat) alskála, önérték index a 3. és 4. mérés esetében is a két csoport között szignifikáns különbség $(\mathrm{p}<0,05)$ látható. Az $\mathrm{O}$ esetében csak a kimeneti mérésnél mutatat szignifikáns különbséget $(\mathrm{p}<0,05)$.

A kísérleti és kontrollcsoport eredményei jól mutatják, hogy közel azonos szintről indultak a tanulók, de a fejlesztő csoportban a differenciált fejlesztés hatására 8. osztály végére minden skála esetében szignifikáns különbség van a két csoport között.

A 5. táblázatban látható, hogy a Levene féle F próba szignifikancia szintje $(p>0,05)$ alapján megegyezik a szórás. Látható, hogy a két nem között minden skála esetében az első (bemeneti) mérésnél és a második mérésnél nincsen szignifikáns különbség $(p>0,05)$. Az iskolai önértékelés (I skála) esetében az ötödik mérésnél, vagyis a kimeneti mérésnél látható szignifikáns különbség $(\mathrm{p}<0,05)$ a két nem között. 
A fejlesztő csoport eredményei mutatják, hogy az önértékelés területeit vizsgálva minimális különbség tapasztalható.

4. táblázat: A fejlesztö és kontrollcsoport Levene féle $F$ próba, kétmintás t-próba eredményei (forrás: a Szerzö)

\begin{tabular}{|c|c|c|c|c|c|c|c|c|c|c|c|c|c|c|c|c|c|c|c|c|}
\hline \multirow{2}{*}{$\frac{\frac{\pi}{\pi}}{\frac{\pi}{n}}$} & \multicolumn{4}{|c|}{$\begin{array}{l}\text { 1. mérés } \\
\text { (bemenet) }\end{array}$} & \multicolumn{4}{|c|}{ 2. mérés } & \multicolumn{4}{|c|}{ 3. mérés } & \multicolumn{4}{|c|}{ 4. mérés } & \multicolumn{4}{|c|}{$\begin{array}{l}\text { 5. mérés } \\
\text { (kimenet) }\end{array}$} \\
\hline & $\mathbf{F}$ & $\mathbf{p}$ & $t$ & $\mathbf{p}$ & $\mathbf{F}$ & $\mathbf{p}$ & $t$ & p & $F$ & $\mathbf{p}$ & $\mathbf{t}$ & $\mathbf{p}$ & $F$ & $\mathbf{p}$ & $\mathbf{t}$ & $\mathbf{p}$ & $\mathbf{F}$ & $\mathbf{p}$ & $\mathbf{t}$ & $\mathbf{p}$ \\
\hline $\mathbf{S}$ & 0,181 & 0,671 & 0,57 & 0,56 & 0,024 & 0,878 & 0,61 & 0,53 & 0,122 & \begin{tabular}{|l|l}
0,727 \\
\end{tabular} & \begin{tabular}{|l|} 
\\
\end{tabular} & 0,80 & \begin{tabular}{|l}
1,300 \\
\end{tabular} & 0,255 & 2,88 & 0,00 & 7,679 & \begin{tabular}{|l}
0,006 \\
\end{tabular} & 2,90 & 0,00 \\
\hline I & 0,002 & $\mid 0,961$ & 0,32 & \begin{tabular}{|l|l|}
0,74 \\
\end{tabular} & \begin{tabular}{|l|l|}
0,012 \\
\end{tabular} & 0,915 & \begin{tabular}{|l|l|}
0,17 \\
\end{tabular} & 0,85 & 0,235 & \begin{tabular}{|l|l}
0,628 \\
\end{tabular} & \begin{tabular}{|l|} 
\\
\end{tabular} & 0,97 & 1,849 & 0,175 & 2,10 & 0,03 & 2,491 & 0,115 & 2,75 & $\mid 0,00$ \\
\hline $\bar{O}$ & 0,151 & 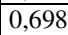 & 0,05 & 0,96 & 0,156 & 0,693 & 0,32 & 0,74 & \begin{tabular}{|l}
0,087 \\
\end{tabular} & 0,768 & $-0,15$ & 0,87 & 0,453 & 0,502 & 0,96 & 0,33 & ,155 & 0,694 & 1,98 & \begin{tabular}{|l|}
0,04 \\
\end{tabular} \\
\hline$T$ & 0,035 & 0,851 & 0,19 & 0,84 & 0,052 & 0,819 & 0,45 & 0,65 & 0,981 & 0,323 & \begin{tabular}{|l|l|}
2,16 \\
\end{tabular} & 0,03 & 1,610 & 0,205 & 3,42 & 0,00 &, 006 & 0,940 & 3,83 & 0,00 \\
\hline 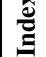 & 0,140 & 0,709 & 0,41 & 0,67 & 0,090 & 0,764 & 0,52 & 0,60 & 0,185 & 0,668 & $\mid-0,21$ & 0,82 & 0,599 & 0,439 & 2,66 & 0,00 & 4,045 & 0,045 & 2,46 & 0,01 \\
\hline
\end{tabular}

5. táblázat. A fejlesztö csoport nemek közötti Levene féle $F$ próba, kétmintás t-próba eredményei (forrás: a Szerzö)

\begin{tabular}{|c|c|c|c|c|c|c|c|c|c|c|c|c|c|c|c|c|c|c|c|c|}
\hline \multirow{2}{*}{$\frac{\text { II }}{\frac{\pi}{Z}}$} & \multicolumn{4}{|c|}{$\begin{array}{l}\text { 1. mérés } \\
\text { (bemenet) }\end{array}$} & \multicolumn{4}{|c|}{ 2. mérés } & \multicolumn{4}{|c|}{ 3. mérés } & \multicolumn{4}{|c|}{ 4. mérés } & \multicolumn{4}{|c|}{$\begin{array}{l}\text { 5. mérés } \\
\text { (kimenet) }\end{array}$} \\
\hline & $\mathbf{F}$ & p & $\mathbf{t}$ & $\mathbf{p}$ & $\mathbf{F}$ & p & $\mathbf{t}$ & p & $\mathbf{F}$ & p & $\mathbf{t}$ & $\mathbf{p}$ & $\mathbf{F}$ & p & $\mathbf{t}$ & p & $\mathbf{F}$ & p & $\mathbf{t}$ & p \\
\hline $\mathbf{S}$ & 1,947 & 0,165 & 0,08 & 0,933 & 0,997 & ,319 & $-0,00$ & 0,996 & 1,384 & 0,241 & $-0,08$ & 0,929 & 0,692 & 0,407 & 1,27 & 0,206 & 4,059 & 0,045 & $-0,19$ & 0,849 \\
\hline $\mathbf{I}$ & 0,460 & 0,499 & \begin{tabular}{|l|}
1,27 \\
\end{tabular} & 0,204 & 0,368 & 0,545 & $-0,45$ & 0,643 & 0,358 & 0,551 & 0,09 & 0,924 & 1,106 & 0,294 & 0,73 & 0,465 & 1,043 & 0,309 & $-2,31$ & 0,022 \\
\hline O & 0,162 & 0,688 & $-0,26$ & 0,792 & 1,629 & 0,203 & $-0,68$ & 0,497 & 1,537 & 0,217 & $-0,74$ & 0,461 & 0,138 & 0,711 & $-0,11$ & 0,909 & 1,204 & 0,274 & $-0,35$ & 0,724 \\
\hline $\mathbf{T}$ & 1,170 & 0,281 & \begin{tabular}{|l|}
$-0,29$ \\
\end{tabular} & 0,771 & 0,026 & 0,871 & $-0,19$ & 0,847 & 0,074 & 0,786 & $-0,75$ & 0,453 & 0,140 & 0,709 & 0,41 & 0,681 & 0,080 & 0,777 & \begin{tabular}{|l}
$-0,93$ \\
\end{tabular} & 0,353 \\
\hline 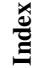 & 0,694 & 0,406 & 0,19 & 0,845 & 1,750 & 0,188 & $-0,30$ & 0,764 & 1,568 & 0,212 & $-0,28$ & 0,777 & 1,298 & 0,256 & 0,92 & 0,354 & 1,352 & 0,247 & $-0,31$ & 0,751 \\
\hline
\end{tabular}

A 6. táblázatban látható, hogy a Levene féle $F$ próba szignifikancia szintje $(p>0,05)$ alapján megegyezik a szórás. A két nem között minden skála esetében az első (bemeneti) mérésnél és a második mérésnél nincsen szignifikáns különbség ( $\mathrm{p}>0,05)$.

A kontrollcsoport eredményei mutatják, hogy az önértékelés területeit vizsgálva minimális különbség tapasztalható.

6. táblázat: A kontrollcsoport nemek közötti Levene féle $F$ próba, kétmintás t-próba eredményei (forrás: a Szerzö)

\begin{tabular}{|c|c|c|c|c|c|c|c|c|c|c|c|c|c|c|c|c|c|c|c|c|}
\hline \multirow[t]{2}{*}{ Skála } & \multicolumn{4}{|c|}{$\begin{array}{l}\text { 1. mérés } \\
\text { (bemenet) }\end{array}$} & \multicolumn{4}{|c|}{ 2. mérés } & \multicolumn{4}{|c|}{ 3. mérés } & \multicolumn{4}{|c|}{ 4. mérés } & \multicolumn{4}{|c|}{$\begin{array}{l}\text { 5. mérés } \\
\text { (kimenet) }\end{array}$} \\
\hline & $\mathbf{F}$ & $\mathbf{p}$ & $\mathbf{t}$ & $\mathbf{p}$ & $\mathbf{F}$ & $\mathbf{p}$ & $\mathbf{t}$ & $\mathbf{p}$ & $\mathbf{F}$ & $\mathbf{p}$ & $\mathbf{t}$ & $\mathbf{p}$ & $\mathbf{F}$ & & $\mathbf{t}$ & $\mathbf{p}$ & $\mathbf{F}$ & $\mathbf{p}$ & $\mathbf{t}$ & $\mathbf{p}$ \\
\hline $\mathbf{S}$ & 3,006 & 0,085 & 0,43 & \begin{tabular}{|l|l|}
0,661 \\
\end{tabular} & 3,121 & 0,079 & 0,42 & 0,67 & 1,814 & 0,180 & 0,5 & 0,579 & 0,259 & 0,611 & $-0,40$ & 0,688 & 0,361 & 0,548 & $-0,43$ & 0,666 \\
\hline I & 4,188 & 0,042 & 0,46 & \begin{tabular}{|l|}
0,640 \\
\end{tabular} & 3,825 & 0,052 & 0,46 & 0,64 & 1,429 & 0,234 & & 0,929 & 0,139 & 0,710 & $-0,51$ & 0,607 & 0,131 & 0,717 & $-1,30$ & 0,19 \\
\hline $\mathbf{O}$ & 1,220 & 0,271 & 0,32 & \begin{tabular}{|l|}
0,750 \\
\end{tabular} & 1,314 & 0,253 & 0,35 & 0,722 & 0,056 & 0,813 & 0,8 & 50,390 & 0,386 & 0,535 & $-0,91$ & 0,362 & 1,228 & 0,269 & $-1,79$ & 0,074 \\
\hline $\mathbf{T}$ & 0,375 & 0,541 & $-0,11$ & 0,908 & 0,530 & 0,468 & $-0,20$ & 0,83 & 0,282 & 0,596 & 0,5 & 0,59 & 0,005 & 0,946 & $-0,24$ & 0,804 & 1,288 & 0,258 & $-0,67$ & 0,50 \\
\hline Index & 2,378 & 0,125 & 0,38 & 0,699 & 2,380 & 0,125 & 0,36 & 0,712 & 1,148 & 0,285 & 0,6 & 40,51 & 0,237 & 0,627 & $-0,61$ & 0,539 & 1,954 & 0,164 & $-1,09$ & 0,276 \\
\hline
\end{tabular}

A reális önértékelés kialakulása lehetővé teszi a világban való könnyebb eligazodást, saját képességeink, korlátaink megismerését. Ebben kiemelkedő szerepe van a családnak, majd később meghatározó elemmé válik az iskola, a pedagógusok és a kortársakkal való kapcsolat kialakítása. 
Varianciaanalízis segítségével a két csoport átlagainak változását és a nemek közötti különbségeket vizsgáltuk. A függő változó az önértékelés alskálái, a független változók pedig az idő, a csoportok és a nemek:

A 3. ábra mutatja a fejlesztő és a kontrollcsoport két nem közötti eltérés eredményeit az $\mathrm{S}$ skála esetében. Az önértékelés fejlődése természetes folyamat az ember életében. Meghatározó elemei: a szülői minta, a nevelői attitűd, a jutalmazás és büntetés következetes alkalmazása, a hibákból való tanulás és a már említett kortársak és pedagógusok hatása. A két ábra mutatja, hogy a két nem közötti önértékelés fejlödés a hatodik osztályt követően jelentősebben eltér. A serdülőkor hatására a két nem eltérő fejlődést mutat a testi változások, a mentális fejlődés és a pszichés érés között. Ennek különböző okai lehetnek, pl: a környezet, a stressz, az agresszió és a konfliktusok. A lányok hamarabb érnek, de gyakrabban jelenik meg náluk a negatívabb önértékelés, ami általában a testképre és a társas kapcsolatokra terjed ki. A kutatás során érdekes volt azt látni, hogy a jól megválasztott tanítási módszerek, a pedagógus személyisége pozitívan befolyásolja a tanulók önértékelését, az egészséges önbizalom kialakítását és egyenletesebbé teszi a két nem közötti önértékelés skálának a fejlődését.

3. ábra: A fejlesztö és kontrollcsoport nemek szerinti átlagainak változása az idő függvényében az $S$ skála esetében (forrás: a Szerzö)
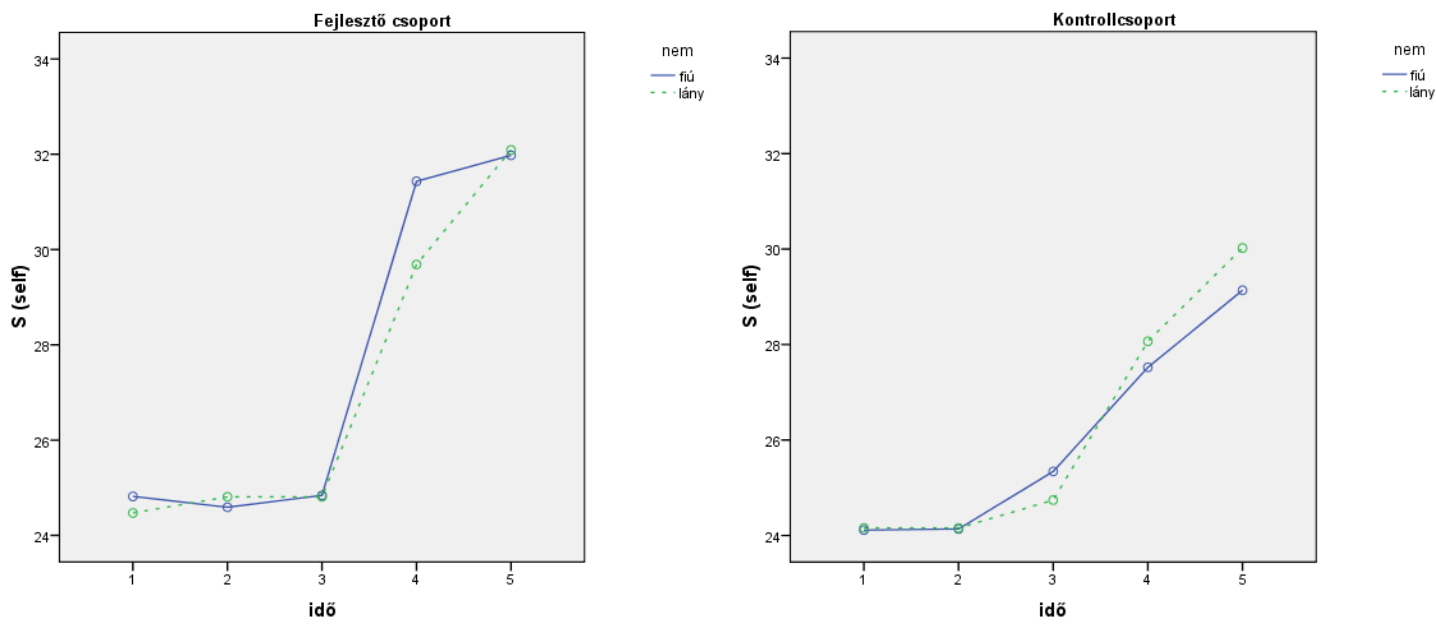

A 4. ábra alapján megfigyelhető, hogy az öt mérés esetében az „S”, vagyis az önértékelés alskála fejlődése változó. Az első és harmadik mérés között fejlesztő csoportnál egyenletes, a kontrollcsoportnál a 2-3. mérés között emelkedő. A folyamatos differenciált fejlesztések hatására a 3. méréstől folyamatosan emelkedés látható. A grafikon a kísérleti csoportnál meredekebb, mint a kontrollnál. A független változók hatása és az interakció is szignifikáns $(\mathrm{p}<0,05)$.

Az általunk vizsgált korcsoport 10-től 14 éves korig magába foglalja a kisiskoláskor végét és a serdülőkor elejét. Ebben az időszakban egyre inkább észrevehető a tanulás iránti motiváció csökkenése és a pedagógus iránti tisztelet is megkérdőjeleződik Az általános iskolákban a differenciált oktatás kiemelt oktatásszervezési módszernek számít, itt is látható, hogy a tudatos, célirányú fejlesztés előnyös változásokat okoz a tanulók fejlődésében. A fejlesztő csoportokban nagyobb arányú az önértékelés fejlődése. Az egészséges önértékelés segíti a társakkal való kapcsolat kialakítását a tanulásban. 
4. ábra: A fejlesztö és kontrollcsoport átlagainak változása az idö függvényében az S skála esetében (forrás: a Szerzö)

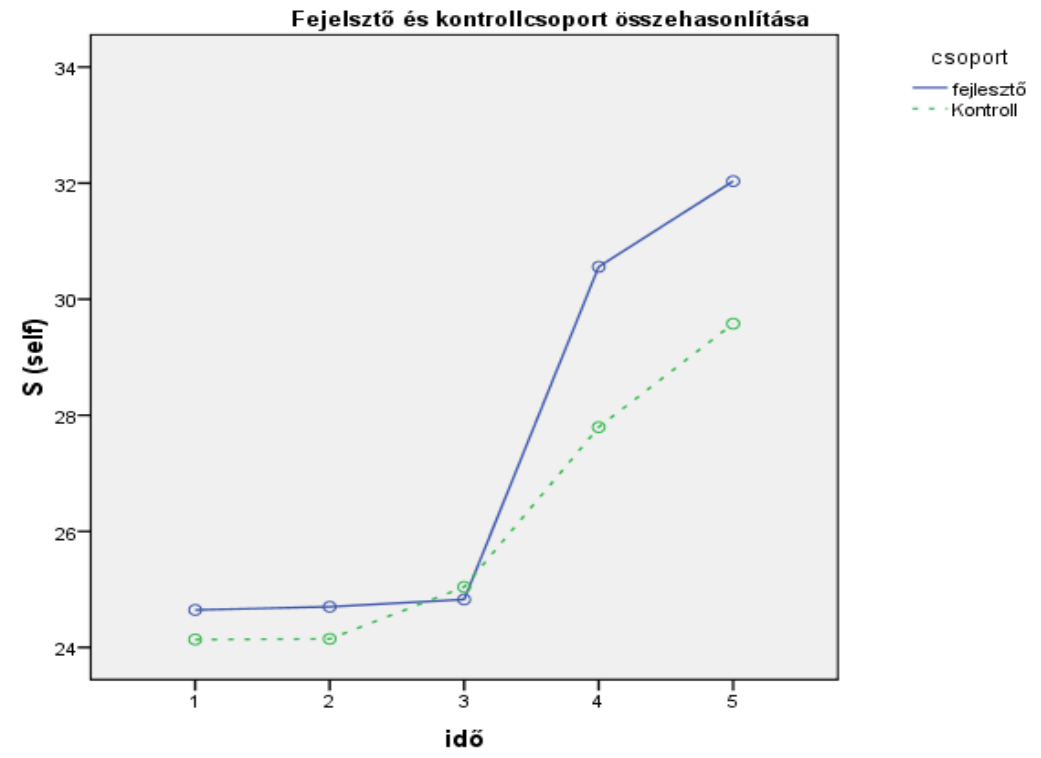

Az 5. ábrán láthatjuk a fejlesztő és a kontrollcsoport iskolai önértékelés eredményeinek változását a négy év kutatása során. Akár a fejlesztő, akár a kontrollcsoport eredményeit nézzük, szembetünő, hogy ebben az alskálában a lányok azok, akik pozitívabb eredményt értek el. Kivételnek tekinthető a fejlesztő csoportnál a harmadik és negyedik mérés közötti eltérés és a kontrollcsoportnál a harmadik mérési eredményt. Ezen kívül azonban a lányok azok, akik pozitívabb képet mutatnak. Ez azért is érdekes eredmény, ugyanis az iskolai önértékelés mindenképpen pozitívan segítheti a társas és az otthoni önértékelés fejlődését. Jogosan merül fel bennünk a kérdés, hogy vajon mi okozza a két nem közötti eltérést. A fejlődéspszichológiai elméletek is alátámasztják, hogy a lányok korai érésének a következménye, hogy másképpen tapasztalják meg a környezetüket, változnak a világról kialakított elképzeléseik, erősödik az empátia és a társas kapcsolatok igénye. Valószínü, hogy a vizsgálat eredményeiben ennek a tükröződését láthatjuk.

5. ábra: A fejlesztö és kontrollcsoport nemek szerinti átlagainak változása az idö függvényében az I skála esetében (forrás: a Szerzö)
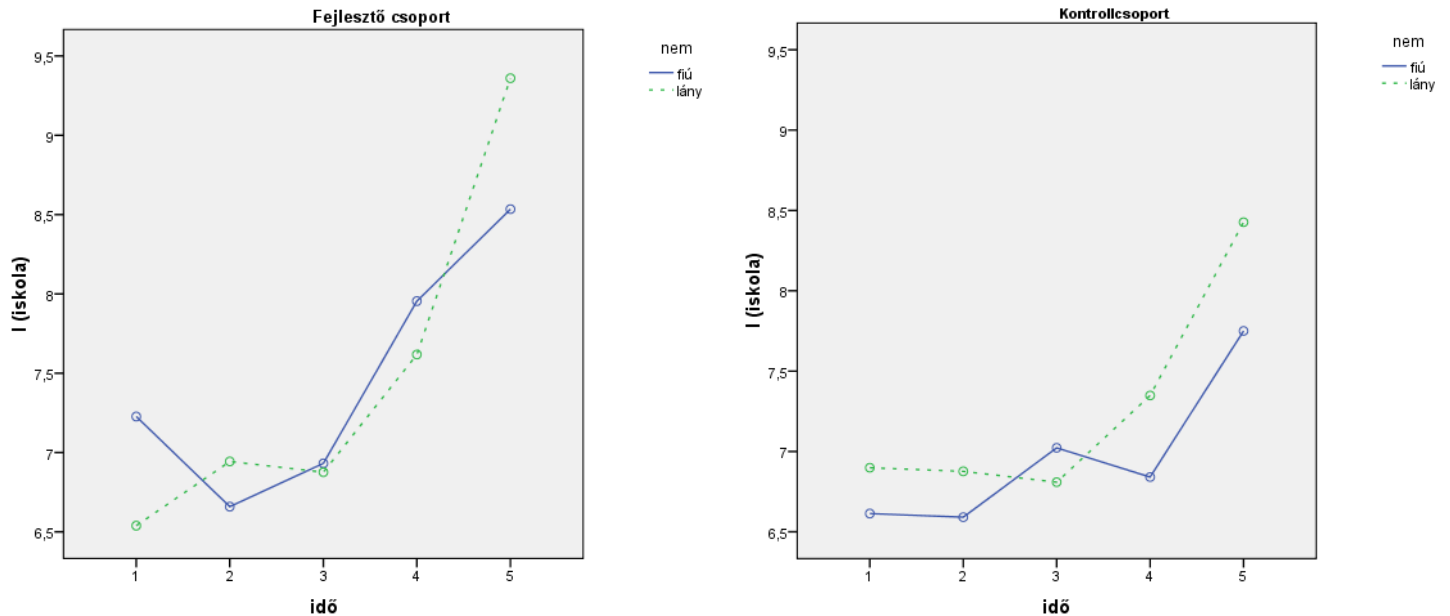
A 6. ábrán az I alskála eredményei láthatóak. Az első és második mérés között mind a két csoportnál csökkenés figyelhető meg. A harmadik és negyedik mérés között intenzív emelkedés tapasztalható a fejlődésben, ami leginkább a fejlesztő csoport eredményében látható. A negyedik és ötödik mérésnél ez a fejlődés tovább fokozódik, a kontrollcsoport eredményeinél is tapasztalunk emelkedést, de a differenciált fejlesztés határára szignifikáns a különbség a két csoport eredményei között. A második év fejlesztő munkáját követően a fejlesztő csoport pozitívabb iskolai önértékelést mutat. A független változók hatása és az interakció is szignifikáns $(\mathrm{p}<0,05)$.

Érdemes azonban arra is kitérni, hogy a kontrollcsoport eredményében az utolsó évben, vagyis a hetedik és a nyolcadik osztályban kimagasló változás tapasztalható. Ha ennek a fejlődéspszichológiai alapját nézzük, akkor valószínü, hogy azért látunk kiugró változás ezen a területen, mert ebben az életkorban fontos lesz a tanulók számára a továbbtanulás, a jövőkép megfogalmazása.

6. ábra: A fejlesztö és kontrollcsoport átlagainak változása az idö függvényében az I skála esetében (forrás: a Szerzö)

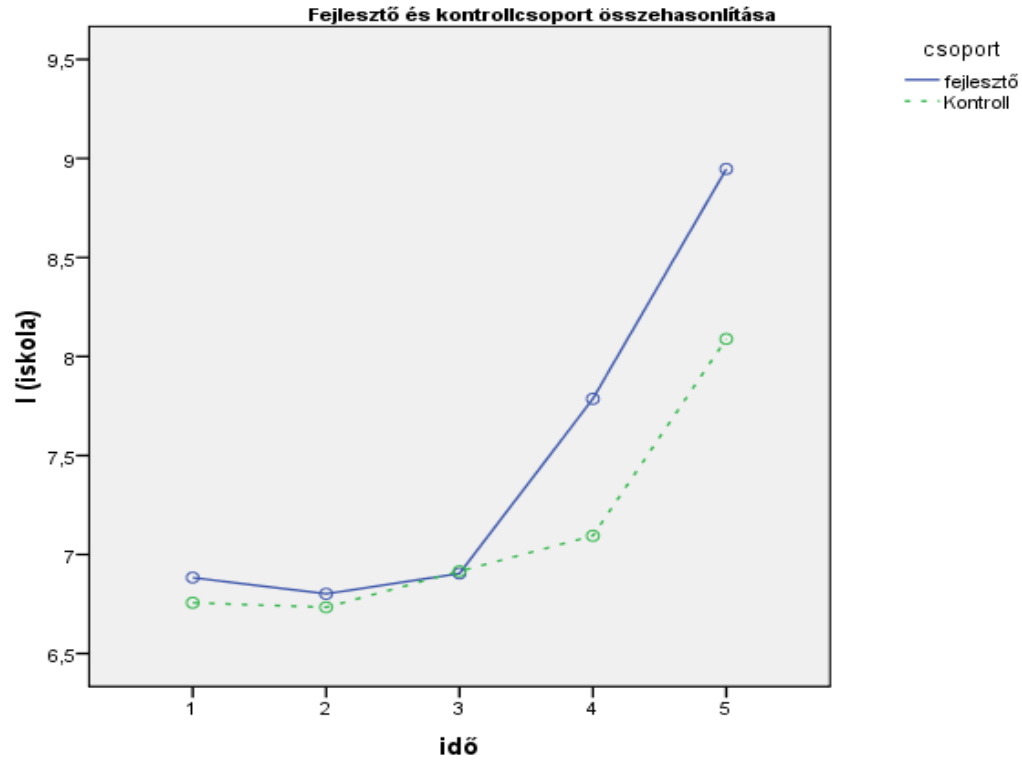

A 7. ábrán látható az O alskála, az otthoni önértékelés fejlesztő és kontrollcsoport két nem közötti eltérésének eredményei Ez a skála méri a tanulók és a szülők kapcsolatát, pontosan megmutatja, hogy a szülök bizalommal és megértéssel fordulnak-e a gyermekeik felé ebben az életkorban, képesek-e megfelelő szabályokat állítani és betartatni a nevelés során. A két nem közötti eltérés mind a két csoportnál szembetünő. A fejlesztő és a kontrollcsoportnál is elválik, és folyamatosan magasabb eredményeket mutat a lányok otthoni önértékelése.

Ebben az életkorban fontosabbá válik a társak szerepe, szívesebben osztják meg a problémáikat a velük egykorú társaikkal, de természetesen maradnak olyan területek is, amelyekben fontos a szülök véleménye, pl: továbbtanulás. A fiúknál tapasztalható a kisebb baráti csoportok kialakítása, melyek általában a hetedik osztálytól kezdve a közös érdeklődésre épülnek. Ezen kívül az eltérésben az is meghatározó jellegü, hogy a lányok ebben az életkorban kommunikítívabbak, mint a velük egykorú fiúk. A lányok gyakrabban és könnyebben elmondják problémáikat, kérdéseiket egy megértő és figyelő felnőttnek. Azonban az eredményekben az is látható, hogy a folyamatos differenciált fejlődés hatására a fiúk és lányok eredményei pozitívabban fejlődnek a kontroll csoporthoz képest. 
7. ábra: A fejlesztö és kontrollcsoport nemek szerinti átlagainak változása az idö függvényében az $O$ skála esetében (forrás: a Szerzö)
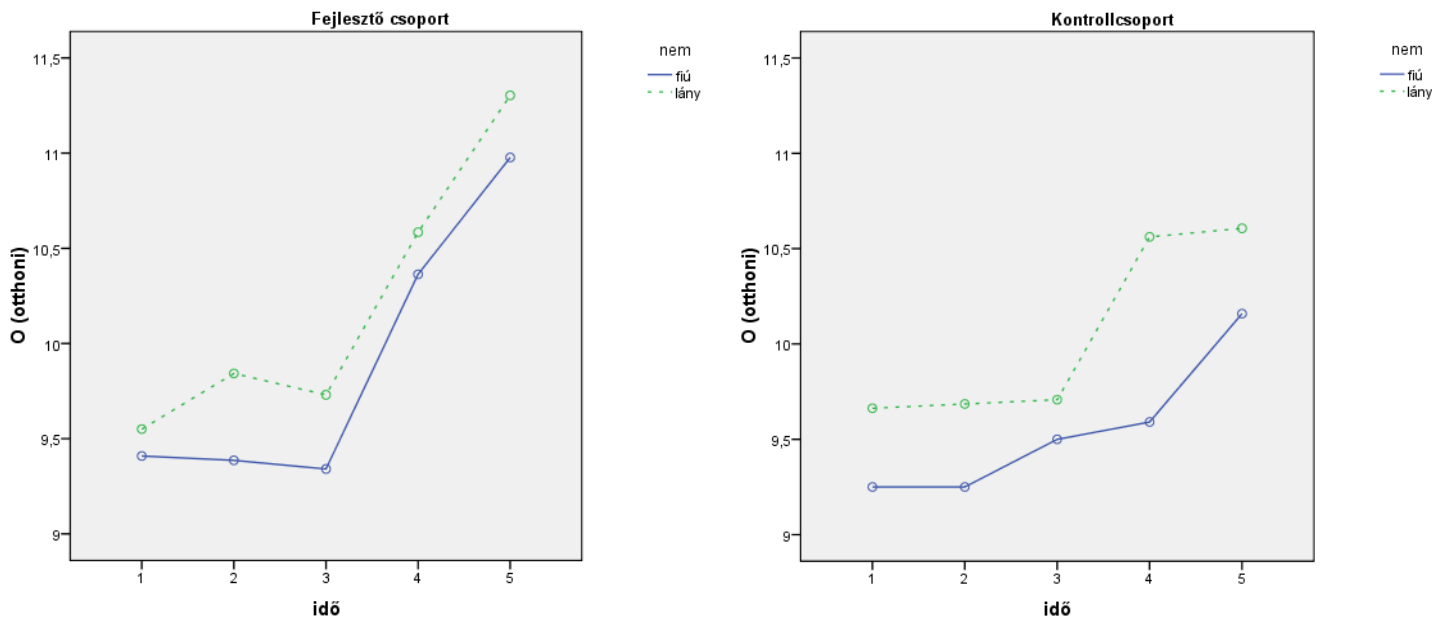

A 8. ábrán a családi önértékelés eredményének bemutatása látható. Bár ezen a területen is kimutatható eltérés a kontroll- és a fejlesztő csoport tesztjei alapján, de a többi eredményhez képest valamivel kisebb a különbség, kisebb mértékü a változás. Az első és második mérés között a kísérleti csoportnál enyhe emelkedés figyelhető meg, a második és harmadik mérés között pedig csökkenés. A kontrollcsoport esetében a második mérés és a harmadik között enyhe emelkedés látható. A további méréseknél már intenzív emelkedés figyelhető meg mind a két csoportnál, a fejlesztőnél ez magasabb szintü, a függvény emelkedése meredekebb, mint a kontrollcsoporté. A független változók hatása és az interakció is szignifikáns $(\mathrm{p}<0,05)$.

8. ábra: A fejlesztő és kontrollcsoport átlagainak változása az idő függvényében az O skála esetében (forrás: a Szerző)

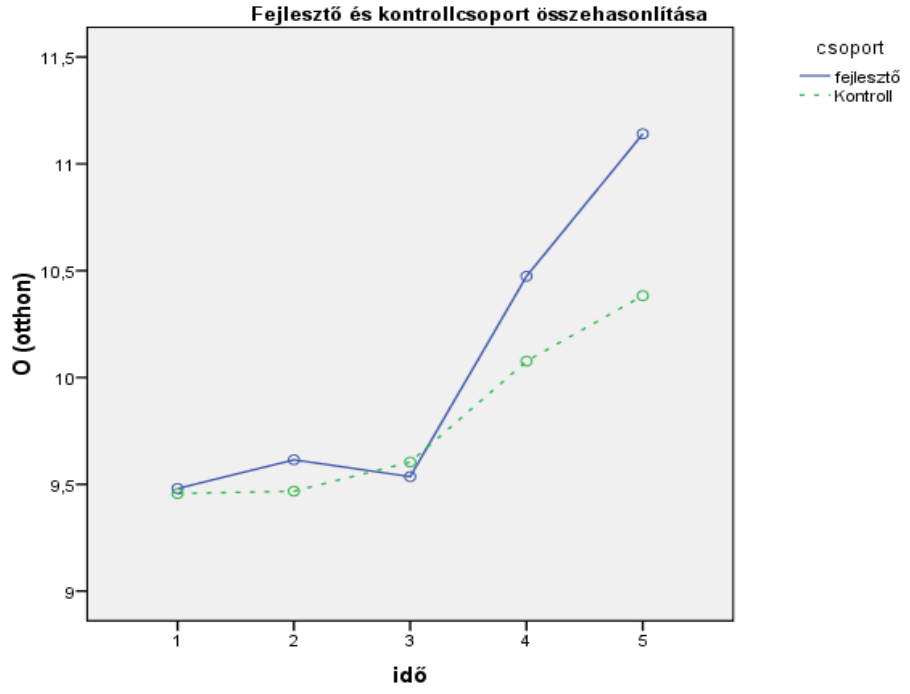

Az önértékelés fejlődésében meghatározó a kortársak, a pedagógusok mellett a szülöi nevelői attitüd. Az ábra azt sugallja, hogy a fejlesztések hatására az önértékelés, az iskola önértékelés és a társakhoz füződő viszony nagyobb fejlődést ér el, de a családi önértékelésben kisebb eredményt lehet elérni. 
A 9. ábra a $\mathrm{T}$ alskála, ami a társakkal kapcsolatos viszonyt mutatja a fejlesztő és a kontrollcsoport két neme között. A fejlődés itt a leginkább eltérő. A folyamatos differenciálás hatására a fejlesztő csoport fiú és lány tagjai magasabb eredményt mutattak a kérdőív feldolgozását követően. A társas kapcsolatok változása alapvető fejlődési folyamat az ember életében. A 10-12 éves gyermekeknél egyre inkább erősödik a társak szerepe, majd 13-14 éves korra a társak véleménye lesz a legmeghatározóbb. Míg kezdetben a közös időtöltés, azonos játék, hobby határozza meg a baráti kapcsolatok létrejöttét, később a szimpátia és a belső tulajdonságok a döntőek. Ezek a baráti társaságok lehetőséget biztosítanak arra, hogy kialakuljanak a csoport szerepek, és az önmagát kereső serdülő énképe, önismerete formálódjon.

9. ábra: A fejlesztő és kontrollcsoport nemek szerinti átlagainak változása az idö függvényében a T skála esetében (forrás: a Szerzö)
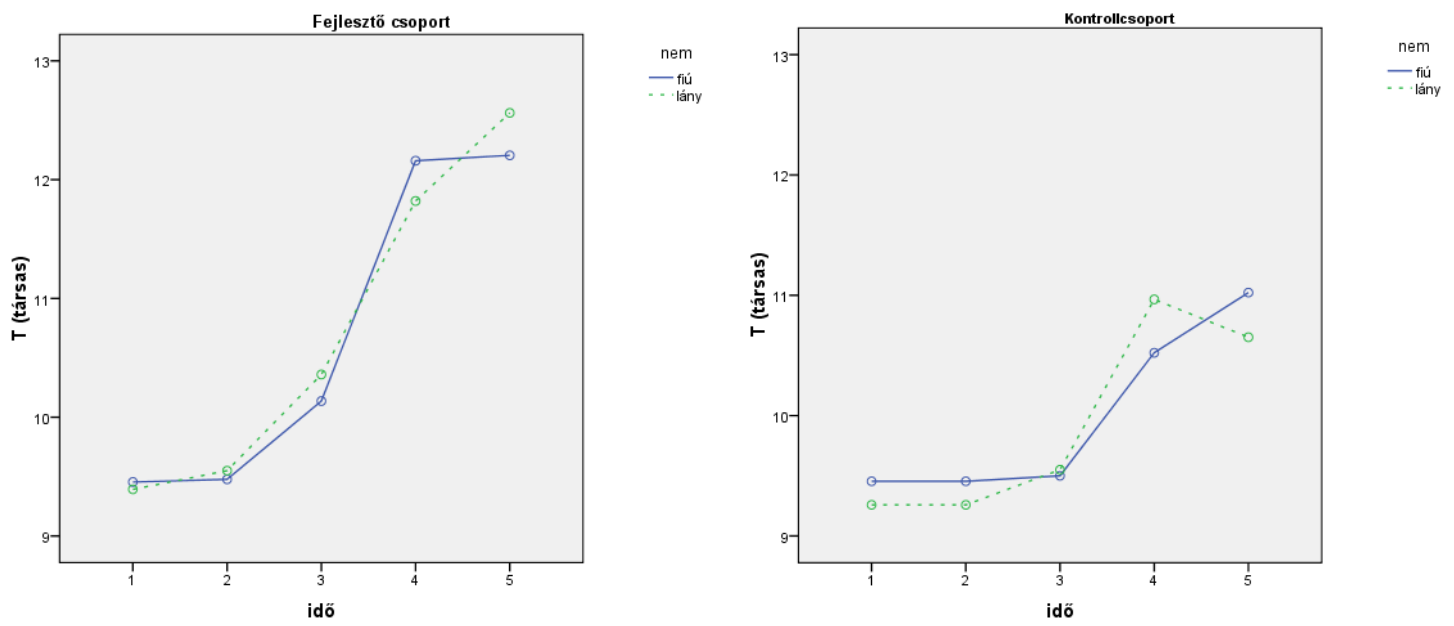

Azonban a két nem között itt is tapasztalhatunk eltéréseket. A lányok intenzívebben élik meg ezeket a társas kapcsolatokat, bár több a konfliktus, a kibékülés, mint a fiúknál, de a kapcsolataik hosszabb távon müködnek.

A 10. ábrán az önértékelés vizsgálata negyedik alskálájának eredményét láthatjuk, ami a társakkal való viszony fejlődését mutatja. Igazi változás a 3. mérés után figyelhető meg, a 4. mérésig igen intenzív az emelkedés mértéke mind a két csoportnál, a fejlesztőnél a grafikon meredeksége nagyobb. A független változók hatása és az interakció is szignifikáns $(\mathrm{p}<0,05)$.

A kortársakkal való kapcsolat változásai 8-9 éves kortól kezdődően folyamatosan változik, hiszen megkezdődik az „átpártolás időszaka”. Az ábra is mutatja, hogy a társakhoz füződő viszony a hatodik osztálytól kezdve pozitív változásokat mutat. A serdülökor elején változik a kapcsolat a szülőkkel, mélyülnek a barátságok, melynek alapját az azonos érdeklődés és az azonos értékek képezik. A leírtakból is látható, hogy bár természetes ebben az időszakban a kortársakhoz való viszony változása, de az ábra azt is mutatja, hogy a céltudatos fejlesztéssel még inkább pozitív eredmény érhető el.

A 11. ábrán az önértékelés index eredményét láthatjuk, ami mutatja az önértékelés fejlődését a kutatás ideje alatta. Kiemelkedő változás a 3. mérés után figyelhető meg, a 4. mérésig igen intenzív az emelkedés mértéke, ami leginkább a fejlesztő csoportnál tapasztalható. A független változók hatása és az interakció is szignifikáns $(\mathrm{p}<0,05)$. Már az eddigi alskálák területeiben is látható, hogy a két nem között eltérés található az önértékelésben. Ebben az indexben láthatjuk, hogy a fejlesztések hatására a fiúk és lányok önértékelése pozitívabban fejlődik, mint a hasonló életkorú kontrollcsoport tagjainál. Az 
önértékelés fejlödésük egészen a 3. vizsgálatig egyformán halad, azonban a 7. osztálytól kezdve szignifikáns eltérést mutat a két csoport eredménye. Eric Erikson pszichoszociális elméletében is kiemeli ennek az életkornak a legfontosabb feladatát, vagyis az identitás elérését, ez azonban kihívás elé állítja a serdülöt és a környezetét egyaránt. A differenciálással az identitás keresésének időszaka a grafikon alapján fejleszthető a tanulóknál.

10. ábra: A fejlesztö és kontrollcsoport átlagainak változása az idő függvényében a T skála esetében (forrás: a Szerzö)

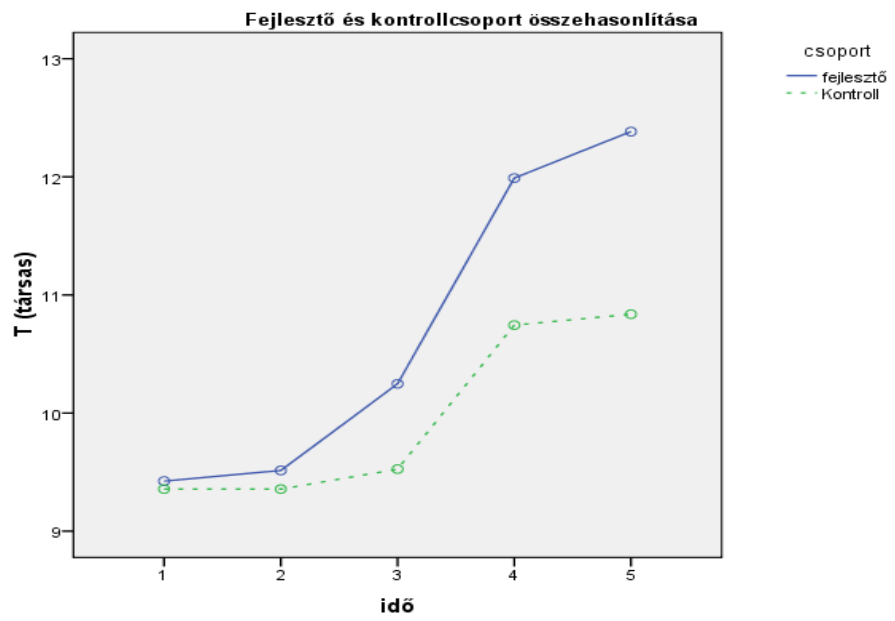

11. ábra: A fejlesztö és kontrollcsoport nemek szerinti átlagainak változása az idö függvényében az önérték index esetében (forrás: a Szerzö)
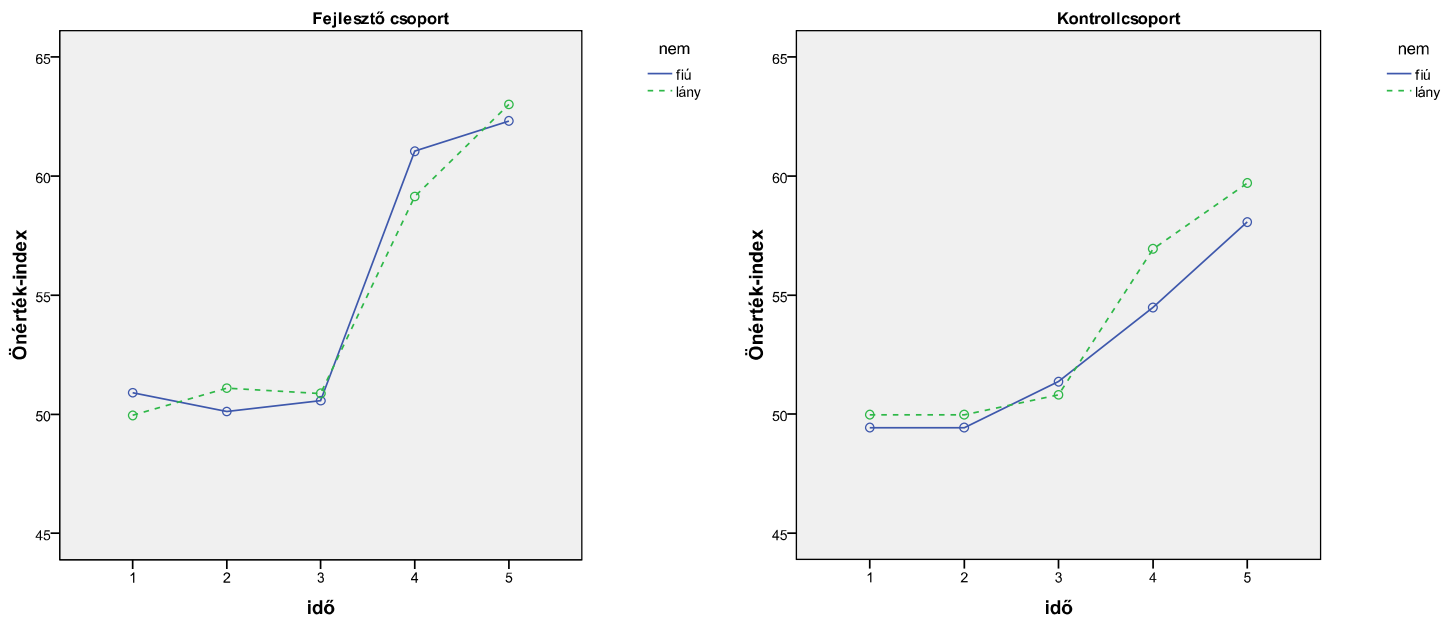

A 12. ábrán a fejlesztő és a kontrollcsoport önértékelés-index eredményeit láthatjuk összehasonlítva. Kiemelkedő változás a 3. mérés után figyelhető meg, a 4. mérésig intenzív az emelkedés mértéke mind a két csoportnál, azonban a kísérleti csoportnál a grafikon meredeksége nagyobb. A független változók hatása és az interakció is szignifikáns $(\mathrm{p}<0,05)$.

A szülők, az iskola, a pedagógusok és a kortársak befolyásolják a tanulók önértékelés fejlődését. Ez azonban nagyon összetett feladat, hiszen mindamellett, hogy meghatározó a 
szülöi minta, a szülői nevelö attitüd és a jutalmazások és büntetések következetes alkalmazása, az iskolának, a pedagógusoknak legalább ennyire figyelembe kell vennie a tanulók egyéni sajátosságait. Az ábrán jól látható, hogy a megfelelő differenciált fejlesztés pozitívan fejleszti az önérték-indexet, hiszen a harmadik méréstöl folyamatosan és intenzíven emelkedik ez a terület.

12. ábra: A fejlesztö és kontrollcsoport átlagainak változása az idö függvényében az önérték-index esetében (forrás: a Szerzö)

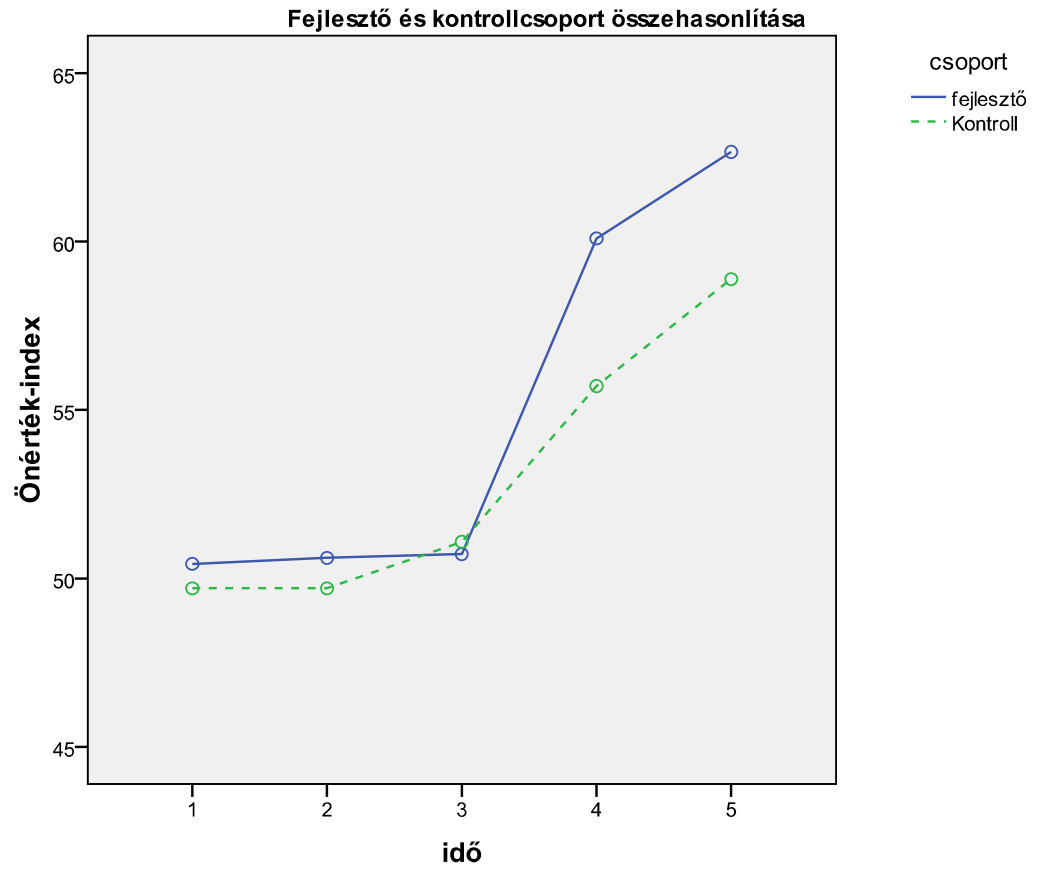

\section{Következtetés}

Ebben a tanulmányban az iskolai differenciálás személyiségre gyakorolt hatásának nagyobb ívü vizsgálatából az önértékelés mérésének eredményeit mutattuk be. A differenciálás, vagyis az „egyéni bánásmód” szükségét régóta hangoztatja a pedagógia, ennek köszönhetően nagyon sok elmélet, módszer született, de mind a mai napig nagyon nehéz kérdés a gyakorlatban a differenciálás. Az adott osztályokba járó tanulók között nagyon nagy eltérések tapasztalhatóak, akár mentális, akár képességbeli különbségek alapján. Varga Tamás 1971ben végzett vizsgálatában meghatározta, hogy a mentális fejlettség alapján 100 gyermek közül, csak 26 járhatna 4. osztályba, a többi gyermek 1-3. illetve 5-8. osztályba lehetne (Fehér Irén, 2001, 310. ).

A differenciálásról alkotott képe a pedagógusoknak egyre inkább formálódik az ismeretek és a gyakorlati tapasztalatok hatására. Ezt mutatja Petriné és munkatársai újabb kutatása. Az értékelés alapján elmondható, hogy egyre nagyobb ismerettel rendelkeznek a pedagógusok a gyermek megismerésével és az egyéni bánásmóddal kapcsolatban, de ezeket „leegyszerüsítve” alkalmazzák a gyakorlatban és sok esetben még mindig ellentmondásosan viszonyulnak a differenciáláshoz (Petriné, 2001).

Az általunk végzett kutatás éppen arra akar rámutatni, hogy a tanulók fejlődésében, a társas kapcsolataiban, az önértékelésében meghatározó lehet a differenciált oktatás. Az önértékelés vizsgálati eredményeiből megállapítható, hogy a tudatos differenciálás hatására ebben az 
életkorban jelentős változások tapasztalhatók az önértékelésben, amit a Coopersmith-féle kérdőív valamennyi alskálája jelez. Kiinduló hipotézisünket ezzel igazoltnak véljük: a differenciált oktatásszervezési forma előnyösen befolyásolja a diákok önértékelését. A tanulmány célja, hogy felhívja arra a figyelmet, hogy a pedagógiában a megfelelő módszerek használatával komoly fejlödést lehet elérni a személyiség területén (is). A megfelelö továbbképzések és tájékoztatások segítséget adhatnak abban a pedagógusoknak, hogy hogyan alkalmazhatják a mindennapi pedagógiai munkában a fejlesztés adta lehetőségeket. Ehhez azonban a pedagógusoknak érezniük kell azt a lehetőséget, amelyet a differenciált oktatás biztosít számukra.

Ami a kutatás korlátait jelenti, az a Coopersmith-féle kérdőív hazai használatában keresendő. A teszthez magyar normatív adatok nincsenek, amik vannak, azok nem reprezentatív mintából származnak. Amerikai adatok ugyan vannak, ám ezek csak pénzért férhetők hozzá. Így azt kell mondanunk, hogy a következtetések elsősorban az adott mintára érvényesek. Érdemes lenne magyar normákat kidolgozni a kérdőívhez.

\section{Irodalom}

Blascovich, J. és Tomaka, J. (1990): Measures of self-esteem. In: Robinson, J., Shaver, Ph. és Wrightsman, L. (Eds.), Measures of personality and social psychological attitudes, Volume 1. New York: Academic Press.

Brookover, W. B. (1959): A social-psychological conception of classroom learning. School and Society, 87. 84-87.

Brown, J. D. és Marshall, M. A. (2006): The three faces of self-esteem. In M. Kernis (Ed.), Self-esteem: Issues and answers. New York, Psychology Press. 4-9.

Coopersmith, S. (1967): The antecedens of self-esteem. San Francisco: W. H. Freeman \& Co.

Coopersmith, S. (1982): Self-esteem inventories. Palo Alto, CA: Consulting Psychologists Press.

Dauenbeimer, D. G., Stablberg, D., Spreemann, S. és Sedikides, C. (2002): Self-enhancement, self-verification, or self-assessment: the intricate role of trait modifiability in the selfevaluation process. Revue internationale de psychologie sociale, 15, (3-4), 89-112.

Fehér Irén (szerk.) (2001): Pedagógia és pszichológia. Comenius, Pécs.

Goserud, Erik J.J. (2015). What Are the Different Theories of Self-Esteem?. Letöltve: 2015. 02. 24-én. Web: www.wisegeekhealth.com/what-are-the-different-theories-of-selfesteem.htm

Helmke, A., Van Aken, M.A.G. (1995): The causal ordering of academic achievement and self-concept of ability during elementary school: A longitudinal study. Journal of Educational Psychology, 87. 624-637.

Körössy Judit (1997): Az énkép és összefüggése az iskolai teljesítménnyel. In: Mészáros Aranka (szerk.): Az iskola szociálpszichológiai jelenségvilága. ELTE Eötvös Kiadó. Budapest.

Marshall, H. (1997). Motivation and motivational strategies. Columbia Univ.

Net1: Letöltés: 2015.12.01. Web: http//:macses.ucsf.edu/Research/Psychosocial/notebook/ selfesteem.html

Petriné Fejér Judit (2001): Pedagógusok a differenciálásról: In Golnhofer, E, Nahalka (szerk.) A pedagógusok pedagógiája. Nemzeti Tankönyvkiadó, Budapest.

Pullmann, H., Allik, J. és Realo, A. (2009): Global self-esteem across the life span: A crosssectional comparison between representative and self-selected internet samples. Experimental Aging Research, 35, 20-44.

Réthy Endréné (2003). Motiváció, tanulás, tanítás. Miért tanulunk jól vagy rosszul? Nemzeti Tankönyvkiadó, Budapest. 
Robins, R. W., Trzesniewski, K. H., Tracy, J. L., Gosling, S. D., és Potter, J. (2002): Global self-esteem across the life span. Psychology and Aging, 17, 423-434.

Tókos Katalin (2005). A serdülökori önismeret az elméleti és empirikus kutatások tükrében pedagógiai megközelítésben. Új Pedagógiai Szemle. 55. évf. 10. sz. Október. 42-60.

Tóth László (2005). Pszichológiai vizsgálati módszerek a tanulók megismeréséhez. Pedellus Tankönyvkiadó, Debrecen. 


\section{Melléklet}

\section{Coopersmith-féle önértékelési kérdőív}

Név:.

Osztály:...... Életkor:

Dátum:

Légy szíves, tégy egy jelet az itt látható állítások mindegyikéhez a következő módon:

Ha az illető állítás olyasmit fejez ki, amit te általában érezni szoktál, akkor a „Jellemző rám” oszlopába tedd az $\mathrm{X}$ jelet!

Ha az illető állítás NEM olyat mond, amit te általában érezni szoktál, akkor a „Nem jellemző rám” oszlopába tedd az X jelet!

Itt nincs helyes vagy helytelen válasz.

\begin{tabular}{|c|c|c|}
\hline Állítás & Jellemző rám & $\begin{array}{c}\text { Nem jellemzó } \\
\text { rám }\end{array}$ \\
\hline \multicolumn{3}{|l|}{ 1. Sokszor álmodozom, ábrándozom. } \\
\hline \multicolumn{3}{|l|}{ 2. Magabiztos vagyok. } \\
\hline \multicolumn{3}{|l|}{ 3. Sokszor szeretnék másvalaki lenni. } \\
\hline \multicolumn{3}{|l|}{ 4. Engem könnyü megszeretni. } \\
\hline \multicolumn{3}{|c|}{ 5. Nagyon élvezem, ha valamit együtt csinálhatok szüleimmel. } \\
\hline \multicolumn{3}{|c|}{ 6. Sohasem szoktam aggódni. } \\
\hline \multicolumn{3}{|l|}{ 7. Nehezemre esik az osztály előtt beszélni. } \\
\hline \multicolumn{3}{|l|}{ 8. Szeretnék fiatalabb lenni. } \\
\hline \multicolumn{3}{|c|}{$\begin{array}{l}\text { 9. Sok mindent megváltoztatnék magammal kapcsolatban, ha képes } \\
\text { lennék rá. }\end{array}$} \\
\hline \multicolumn{3}{|l|}{ 10. Általában könnyen tudok dönteni. } \\
\hline \multicolumn{3}{|l|}{ 11. Szívesen vannak velem a többiek. } \\
\hline \multicolumn{3}{|l|}{ 12. Otthon könnyen kijövök a sodromból. } \\
\hline \multicolumn{3}{|l|}{ 13. Én mindig helyesen cselekszem. } \\
\hline \multicolumn{3}{|c|}{ 14. Elégedett vagyok az iskolai teljesítményemmel. } \\
\hline \multicolumn{3}{|c|}{ 15. Nekem kell, hogy valaki mindig megmondja, mit csináljak. } \\
\hline \multicolumn{3}{|c|}{ 16. Nehezen szokom meg az új dolgokat. } \\
\hline \multicolumn{3}{|l|}{ 17. Gyakran megbánom azt, amit teszek. } \\
\hline \multicolumn{3}{|l|}{ 18. Népszerü vagyok a társaim között. } \\
\hline \multicolumn{3}{|l|}{ 19. A szüleim tekintettel vannak érzelmeimre. } \\
\hline \multicolumn{3}{|l|}{ 20. Sohasem vagyok boldogtalan. } \\
\hline \multicolumn{3}{|c|}{ 21. Olyan jól dolgozom, amennyire csak tudok. } \\
\hline \multicolumn{3}{|c|}{ 22. Könnyen megadom magam, feladom az erőfeszítést. } \\
\hline \multicolumn{3}{|c|}{ 23. Tudok vigyázni magamra. } \\
\hline \multicolumn{3}{|c|}{ 24. Boldog gyerek vagyok. } \\
\hline \multicolumn{3}{|c|}{ 25. Szívesebben vagyok nálam kisebb gyerekekkel. } \\
\hline \multicolumn{3}{|c|}{ 26. A szüleim túl sokat várnak tőlem. } \\
\hline \multicolumn{3}{|l|}{ 27. Mindenkit szeretek, akit csak ismerek. } \\
\hline \multicolumn{3}{|l|}{ 28. Szeretem, ha engem kérdeznek az órán. } \\
\hline \multicolumn{3}{|l|}{ 29. Tisztában vagyok önmagammal. } \\
\hline 30. Néha nehezen viselem el saját magamat. & & \\
\hline
\end{tabular}




\begin{tabular}{|l|l|l|}
\hline 31. Az életemben sok minden zavaros. & & \\
\hline 32. Az osztálytársaim hallgatnak rám. & & \\
\hline 33. Otthon senki sem figyel rám. & & \\
\hline 34. Engem sohasem szidnak meg. & & \\
\hline 35. Nem dolgozom olyan jól az iskolában, ahogyan szeretném. & & \\
\hline 36. Képes vagyok arra, hogy elhatározzak valamit, s kitartsak mellette. & & \\
\hline 37. Tulajdonképpen nem örülök, & & \\
\hline \multicolumn{1}{|c|}{ hogy fiú (lány)vagyok (olyan nemú, ami vagy). } & & \\
\hline 38. Meglehetösen rossz véleményem van magamról. & & \\
\hline 39. Nem szeretek másokkal lenni. & & \\
\hline 40. Sokszor érzem azt, jobb lenne, ha nem otthon élnék. & & \\
\hline 41. Sohasem vagyok bátortalan. & & \\
\hline 42. Az iskolában gyakran kijövök a sodromból. & & \\
\hline 43. Gyakran szégyenkezem magam miatt. & & \\
\hline 44. Nem vagyok olyan helyes, jó külsejü, mint a többiek. & & \\
\hline 45. Ha valamit meg akarok mondani, azt meg is mondom. & & \\
\hline 46. A társaim gyakran kötekednek velem. & & \\
\hline 47. A szüleim megértenek engem. & & \\
\hline 48. Én mindig megmondom az igazat. & & \\
\hline 49. Sok tanár azt az érzést kelti bennem, & & \\
\hline hogy nem tudok megfelelni a követelményeknek & & \\
\hline 50. Nem törődöm azzal, hogy mi történik velem. & & \\
\hline 51. Nekem semmi sem sikerül. & & \\
\hline 52. Könnyen elvesztem a fejem, mikor megszidnak. & & \\
\hline 53. Másokat jobban szeretnek, mint engem. & & \\
\hline 54. Úgy érzem, a szüleim túl sokat követelnek tölem. & & \\
\hline 55. Én azonnal megtalálom a megfelelö hangot bárkivel. & & \\
\hline 56. Gyakran elcsüggedek az iskolában. & & \\
\hline 57. A dolgok általában nem zökkentenek ki nyugalmamból. & & \\
\hline 58. Rám nemigen lehet számítani. & & \\
\hline
\end{tabular}

Kódolási kulcs a Coopersmith-féle önértékelési kérdőív pontszámainak megállapításához:

\begin{tabular}{|l|l|l|l|l|l|}
\hline $1 .-\mathrm{S}$ & $11 .+\mathrm{T}$ & $21 .+\mathrm{T}$ & $31 .-\mathrm{S}$ & $41 .-\mathrm{L}$ & $51 .-\mathrm{S}$ \\
\hline $2 .+\mathrm{S}$ & $12 .-\mathrm{O}$ & $22 .-\mathrm{S}$ & $32 .+\mathrm{T}$ & $42 .-\mathrm{I}$ & $52 .-\mathrm{S}$ \\
\hline $3 .-\mathrm{S}$ & $13 .-\mathrm{L}$ & $23 .+\mathrm{S}$ & $33 .-\mathrm{O}$ & $43 .-\mathrm{S}$ & $53 .-\mathrm{T}$ \\
\hline $4 .+\mathrm{T}$ & $14 .+\mathrm{I}$ & $24 .+\mathrm{S}$ & $34 .-\mathrm{L}$ & $44 .-\mathrm{S}$ & $54 .-\mathrm{O}$ \\
\hline $5 .+\mathrm{O}$ & $15 .-\mathrm{S}$ & $25 .-\mathrm{T}$ & $35 .-\mathrm{I}$ & $45 .+\mathrm{S}$ & $55 .-\mathrm{L}$ \\
\hline $6 .-\mathrm{L}$ & $16 .-\mathrm{S}$ & $26 .-\mathrm{O}$ & $36 .+\mathrm{S}$ & $46 .-\mathrm{T}$ & $56 .-\mathrm{I}$ \\
\hline $7 .-\mathrm{I}$ & $17 .-\mathrm{S}$ & $27 .-\mathrm{L}$ & $37 .-\mathrm{S}$ & $47 .+\mathrm{O}$ & $57 .+\mathrm{S}$ \\
\hline $8 .-\mathrm{S}$ & $18 .+\mathrm{T}$ & $28 .+\mathrm{I}$ & $38 .-\mathrm{S}$ & $48 .-\mathrm{L}$ & $58 .-\mathrm{S}$ \\
\hline $9 .-\mathrm{S}$ & $19 .+\mathrm{O}$ & $29 .+\mathrm{S}$ & $39 .-\mathrm{T}$ & $49 .-\mathrm{I}$ & \\
\hline $10 .+\mathrm{S}$ & $20 .-\mathrm{L}$ & $30 .-\mathrm{S}$ & $40 .-\mathrm{O}$ & $50 .-\mathrm{S}$ & \\
\hline
\end{tabular}




\section{Maximum értékek:}

- S skála: 52 pont

- I skála: 16 pont

- O skála: 16 pont

- T skála: 16 pont

- Önérték-index: 100 pont.

(Az L skálán kapott pontszámokat nem számítjuk bele az önérték-indexbe.)

A Coopersmith-féle kérdőívvel nyert magyar adatok

\begin{tabular}{lrcclccc} 
& \multicolumn{3}{c}{ Fiúk $(\mathrm{n}=316)$} & \multicolumn{2}{c}{ Lányok $(\mathrm{n}=328)$} & \multicolumn{2}{c}{ Összesen $(\mathrm{n}=644)$} \\
& átlag & szórás & \multicolumn{2}{c}{ átlag } & szórás & átlag & szórás \\
$\mathrm{S}$ (self) & 36,44 & 9,33 & & 8,57 & 9,19 & 37,59 & 9,33 \\
I (iskola) & 9,25 & 4,26 & & 9,96 & 3,74 & 9,69 & 4,50 \\
O (otthon) & 12,67 & 3,60 & & 13,71 & 2,89 & 13,27 & 3,79 \\
T (társak) & 11,33 & 5,28 & & 11,83 & 3,25 & 11,66 & 4,78 \\
Önérték & & & & & & & \\
-index & 69,68 & 17,31 & & 74,06 & 15,26 & 72,21 & 18,08
\end{tabular}

